\title{
Protocol beoordeling essentaksterfte
}

\author{
A.J. van Kuik ${ }^{1}$, J.A. Hiemstra ${ }^{1}$, J. Kopinga ${ }^{2}$, H. Kuppen ${ }^{3}$ en R. Schraven ${ }^{4}$ \\ ${ }^{1}$ Wageningen University and Research \\ ${ }^{2}$ Kopinga Boomadvies \\ ${ }^{3}$ Terra Nostra \\ ${ }^{4}$ BTL Bomendienst
}

Dit protocol voor een uniforme opname van essentaksterfte (ETS) in stedelijke en landelijke omgevingen is door Wageningen University \& Research gemaakt in opdracht van VHG Platform Boomspecialisten en de Intergemeentelijke Studiegroep Bomen (ISB). De digitale versie is te vinden op:

https://doi.org/10.18174/455738

Het protocol maakt onderdeel uit van het rapport "Rapportage ontwikkeling protocol voor uniforme beoordeling essentaksterfte"en is voortgekomen uit een samenwerking van Wageningen UR, Terra Nostra, BTL Boomadvies en Kopinga Boomadvies en is te vinden op: https://doi.org/10.18174/454600

WR is een onderdeel van Wageningen University \& Research, samenwerkingsverband tussen Wageningen University en de Stichting Wageningen Research.

Wageningen, juli 2018

Rapport WPR 2018-08

WAGENINGEN

UNIVERSITY \& RESEARCH

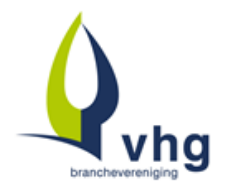

Stadswerk 
Dit protocol is gemaakt voor het beoordelen van de mate van aantasting van de es door ETS in de stedelijke omgeving en landelijke omgeving. Dus voor stadsbomen en essen in beplantingen langs wegen (straat- en laanbomen).

\section{Het protocol bestaat uit een lijst van 22 op te nemen gegevens.}

Het protocol bestaat uit 22 in te voeren velden per boom. Van de 22 velden zitten er 2 in de vaste data (locatie, boomnummer). 2 velden worden automatisch gevuld (datum en waarnemer). Vanuit de administratieve informatie kunnen 3-4 velden overgenomen worden (boomsoort, type standplaats (mogelijk type beplanting) en plantjaar). Er blijven dan 14-15 velden over die ingevuld moeten worden.

Veelal werkt men met het aanvinken van keuzevelden. NB: niet alle velden hoeven altijd ingevuld te worden. Bij bomen waarbij geen ETS aanwezig is hoeven veel velden dus ook niet gemuteerd te worden. Hierdoor blijft het praktisch uitvoerbaar.

Het is wel belangrijk dat bij elke opname alle velden van het protocol worden gebruikt. Deze data moet worden ingewonnen om tenminste iets over aard, omvang en trends te kunnen zeggen, én om de gegevens met elkaar te delen.

De regelmaat van het beoordelen van de bomen wordt aan de boombeheerder overgelaten.

De mate van aantasting wordt beoordeeld door het deel van de kroon waar het blad ontbreekt, op plaatsen waar het wel aanwezig zou moeten zijn, in te schatten.

Tevens wordt ingeschat in welke mate de boom zijn bladoppervlakte tracht te herstellen door waterlotvorming. Hiermee kan de mate van aantasting van essen door ETS van zowel individuele bomen als van een populatie essen worden gevolgd en vergeleken.

Voor het monitoren van ETS in de loop van de tijd is het belangrijk om het type omgeving en het type groeiplaats eveneens vast te leggen. Hiermee kunnen mogelijke invloeden van omgevingsfactoren op het optreden van ETS worden geanalyseerd.

Voor groenbeheerders is het gevaar dat kan ontstaan door afbrekende en uitvallende takken een serieus aandachtspunt. Daarom wordt met dit protocol ook geregistreerd of er afgestorven takken aanwezig zijn. Bij meerjarige monitoring kan dit ook inzicht geven in de snelheid waarmee (zwaar) dood hout wordt gevormd.

Het protocol beschrijft een standaardwijze voor het waarnemen en vastleggen van de belangrijkste aspecten die bij elke opname nodig zijn om onderlinge vergelijking van de resultaten mogelijk te maken.

Daarnaast kan elke opdrachtgever of uitvoerende partij dit verder uitbreiden met andere voor hem of haar van belang zijnde aspecten. Dit protocol maakt het mogelijk om onderbouwde boombeheeradviezen te geven voor Fraxinus-soorten in relatie tot ETS.

NB. Het protocol beperkt zich tot ETS en is niet ontwikkeld voor andere ziekten of aantastingen. Verder maakt de grote variatie van uitingsvormen van ETS in de praktijk het nodig dat de waarnemer is 'geschoold' in het herkennen van ETS en het werken met dit protocol. 


\section{Op te nemen gegevens}

\section{Algemene gegevens}

1. Datum van beoordeling (ddmmyyyy)

2. Locatie boom (X/Y coördinaten, volgens standaard EPSG 28992 coördinatensysteem)

3. Waarnemer (bedrijf + naam waarnemer)

\section{Gegevens groeiplaats}

4. Type beplanting: solitaire boom/ laanbeplanting/ plantsoen/ bomen in bosverband

5. Type standplaats: (half) verharding/ gazon/ ruig gras/ gesloten beplanting/ open grond.

Bepalend hierin is de standplaats waar meer dan $50 \%$ van de kroonprojectie zich bevindt.

\section{Boomgegevens}

6. Boomnummer (uniek)

7. Boomsoort en eventueel cultivar

8. Plantjaar (uit boomregistratiesysteem of inschatten)

9. Diameter op $1.30 \mathrm{~m}$ hoogte

10. Algehele conditie: zie tabel 1.

11. In afgelopen 3 jaar gesnoeid: ja/ nee

12. Aantasting door Armillaria spp. (honingzwam): ja/ nee

13. Andere ziekten, aantastingen of beschadigingen:

\section{Gegevens essentaksterfte (ETS)}

14. Tak-/twijgsterfte aanwezig: ja/ nee

15. Is het ETS: ja/ twijfel/ nee

16. Hoe ver is de aantasting waarneembaar: blad/ twijgen/ takken/ gesteltakken/ stam

17. Percentage bladverlies ten opzichte van de originele kroon ongeacht of aanwezig blad oud of nieuw gevormd is. Zie tabel 2. De bijbehorende beelden op nummer terug te vinden verderop in het protocol.

18. Percentage van het aanwezige blad dat het gevolg is van waterlotvorming. Zie tabel 3. De bijbehorende beelden zijn op nummer terug te vinden verderop in het protocol.

19. Aanwezigheid afgestorven plekken bast op stam (bastaantasting): $0 / 1 / 2 /$ meer dan 2. Zie foto hieronder.

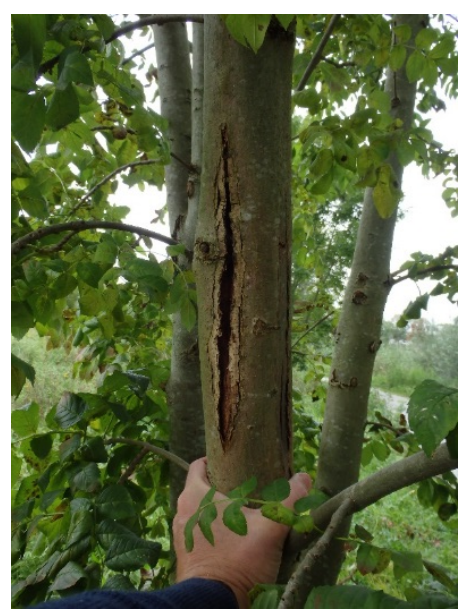

20. Aanwezigheid afgestorven takken, dikker dan $4 \mathrm{~cm} /$ of dunner dan $4 \mathrm{~cm}$ en langer dan $100 \mathrm{~cm}$ : ja/ nee

21. Maximale diameter afgestorven takken: schatten in $\mathrm{cm}$

22. Aftakelingsklasse. Zie tabel 4. De bijbehorende beelden zijn op nummer terug te vinden verderop in het protocol. 
Tabel 1. Conditieklassen met omschrijving van kenmerken.

\begin{tabular}{|c|c|c|}
\hline nummer & Conditieklasse & Kenmerken \\
\hline 1 & Goed & $\begin{array}{l}\text { Boom vertoont gewenste (optimale) soort-specifieke groei, wat zichtbaar } \\
\text { is aan de goede twijggroei en knopontwikkeling. De boom vertoont het } \\
\text { beeld dat van de soort verwacht mag worden onder goede } \\
\text { groeiomstandigheden en op een goede groeiplaats. }\end{array}$ \\
\hline 2 & Redelijk & $\begin{array}{l}\text { Boom vertoont niet optimale groei, wat zichtbaar is aan de verminderde } \\
\text { scheutlengte en de meer transparante kroon als gevolg van verminderde } \\
\text { ontwikkeling van zijknoppen. De verminderde (groei) omstandigheden } \\
\text { hebben nog geen duidelijke negatieve gevolgen voor de verdere } \\
\text { ontwikkeling. }\end{array}$ \\
\hline 3 & Matig & $\begin{array}{l}\text { Boom verkeert in een (sterk) verminderde conditie, wat zichtbaar is aan } \\
\text { de transparante kroon door (deels) afstervende twijgen, matige } \\
\text { twijggroei, afstervende takuiteinden en regeneratiegroei op } \\
\text { hoofdgesteltakken. De levensverwachting van de boom is (sterk) } \\
\text { verminderd. Het proces is echter nog omkeerbaar. }\end{array}$ \\
\hline 4 & Slecht & $\begin{array}{l}\text { De boom vertoont duidelijke signalen van algehele aftakeling, wat } \\
\text { zichtbaar is aan forse kroonsterfte en zeer beperkte groei. De } \\
\text { levensverwachting van de boom is ernstig verminderd. Duidelijk } \\
\text { aftakelende boom, waarbij veelal sprake is van een ijle kroon, met } \\
\text { scheutsterfte resulterend in veel en soms dikke afgestorven takken. }\end{array}$ \\
\hline 5 & Zeer slecht & De boom is op sterven na dood. \\
\hline
\end{tabular}

Tabel 2. Ziekteklassen te gebruiken voor het scoren van bladverlies (ontbrekend blad).

\begin{tabular}{|c|c|c|}
\hline $\begin{array}{c}\text { Ziekteklasse/ } \\
\text { bladverlies }\end{array}$ & $\begin{array}{c}\text { Aangetast deel kroon/ percentage ontbrekend deel } \\
\text { bladvolume }\end{array}$ & $\begin{array}{c}\text { Corresponderend } \\
\text { afbeeldingsnummer }\end{array}$ \\
\hline 0 & $0 \%$ (geen symptomen) & 1 a, b \\
\hline 1 & $<5 \%, b$ \\
\hline 2 & $5-20 \%$ & $3 \mathrm{a}, \mathrm{b}$ \\
\hline 3 & $21-50 \%$ & $4 \mathrm{a}, \mathrm{b}$ \\
\hline 4 & $51-80 \%, \mathrm{a}, \mathrm{b}$ \\
\hline 5 & $81-99 \%$ & $6 \mathrm{a}, \mathrm{b}$ \\
\hline 6 & $100 \%$ & $7 \mathrm{a}, \mathrm{b}$ \\
\hline
\end{tabular}

Tabel 3. Percentage blad door waterlotvorming, verdeeld in 6 klassen

\begin{tabular}{|c|c|c|}
\hline klasse & Percentage blad afkomstig van waterlotvorming & $\begin{array}{c}\text { Corresponderend } \\
\text { afbeeldingsnummer }\end{array}$ \\
\hline 0 & (Geen symptomen) & $1 \mathrm{a}, \mathrm{b}$ \\
\hline 1 & $<5 \%$ & $8 \mathrm{a}, \mathrm{b}$ \\
\hline 2 & $5-20 \%$ & $9 \mathrm{a}, \mathrm{b}$ \\
\hline 3 & $21-50 \%$ & $10 \mathrm{a}, \mathrm{b}$ \\
\hline 4 & $51-80 \%$ & $11 \mathrm{a}, \mathrm{b}$ \\
\hline 5 & $81-99 \%$ & $12 \mathrm{a}, \mathrm{b}$ \\
\hline 6 & $100 \%$ & $13 \mathrm{a}, \mathrm{b}$ \\
\hline
\end{tabular}


Tabel 4. Ziekteklassen gebaseerd op de voortgang van ETS in individuele bomen.

\begin{tabular}{|c|c|c|c|c|}
\hline Ziekteklasse & Omschrijving & $\begin{array}{c}\text { Schematische } \\
\text { weergave }\end{array}$ & Beschrijving & $\begin{array}{l}\text { Corresponderend } \\
\text { afbeeldingsnummer }\end{array}$ \\
\hline 0 & $\begin{array}{c}\text { Geen } \\
\text { aantasting }\end{array}$ & & $\begin{array}{c}\text { Geen symptomen van } \\
\text { aantasting door ETS } \\
\text { zichtbaar. }\end{array}$ & $1 a, b$ \\
\hline 1 & $\begin{array}{c}\text { Licht } \\
\text { aangetast }\end{array}$ & & $\begin{array}{c}\text { Beperkte symptomen op } \\
\text { één of enkele scheuten: } \\
\text { bruin, verwelkt of } \\
\text { verdroogd blad en/of } \\
\text { enkele } \\
\text { aantastingsplekken op } \\
\text { twijgen of stam. }\end{array}$ & $14 a, b$ \\
\hline 2 & $\begin{array}{c}\text { Matig } \\
\text { aangetast }\end{array}$ & & $\begin{array}{c}\text { Meerdere twijgen } \\
\text { afgestorven, afgestorven } \\
\text { aantastingsplekken op } \\
\text { takken en/of stam en } \\
\text { hergroei. }\end{array}$ & $15 a, b$ \\
\hline 3 & $\begin{array}{c}\text { Zwaar } \\
\text { aangetast }\end{array}$ & & $\begin{array}{c}\text { Groot deel van de } \\
\text { scheuten en eventueel } \\
\text { ook deel van stam } \\
\text { afgestorven; meerdere } \\
\text { afgestorven } \\
\text { aantastingsplekken op de } \\
\text { stam en hergroei vanuit } \\
\text { de stambasis. }\end{array}$ & $16 a, b$ \\
\hline 4 & Dood & & $\begin{array}{l}\text { Boom geheel } \\
\text { afgestorven. }\end{array}$ & 17 \\
\hline
\end{tabular}


Van alle klassen worden 2 foto's getoond, a en b. Foto's genomen door Henry Kuppen, Terra Nostra.

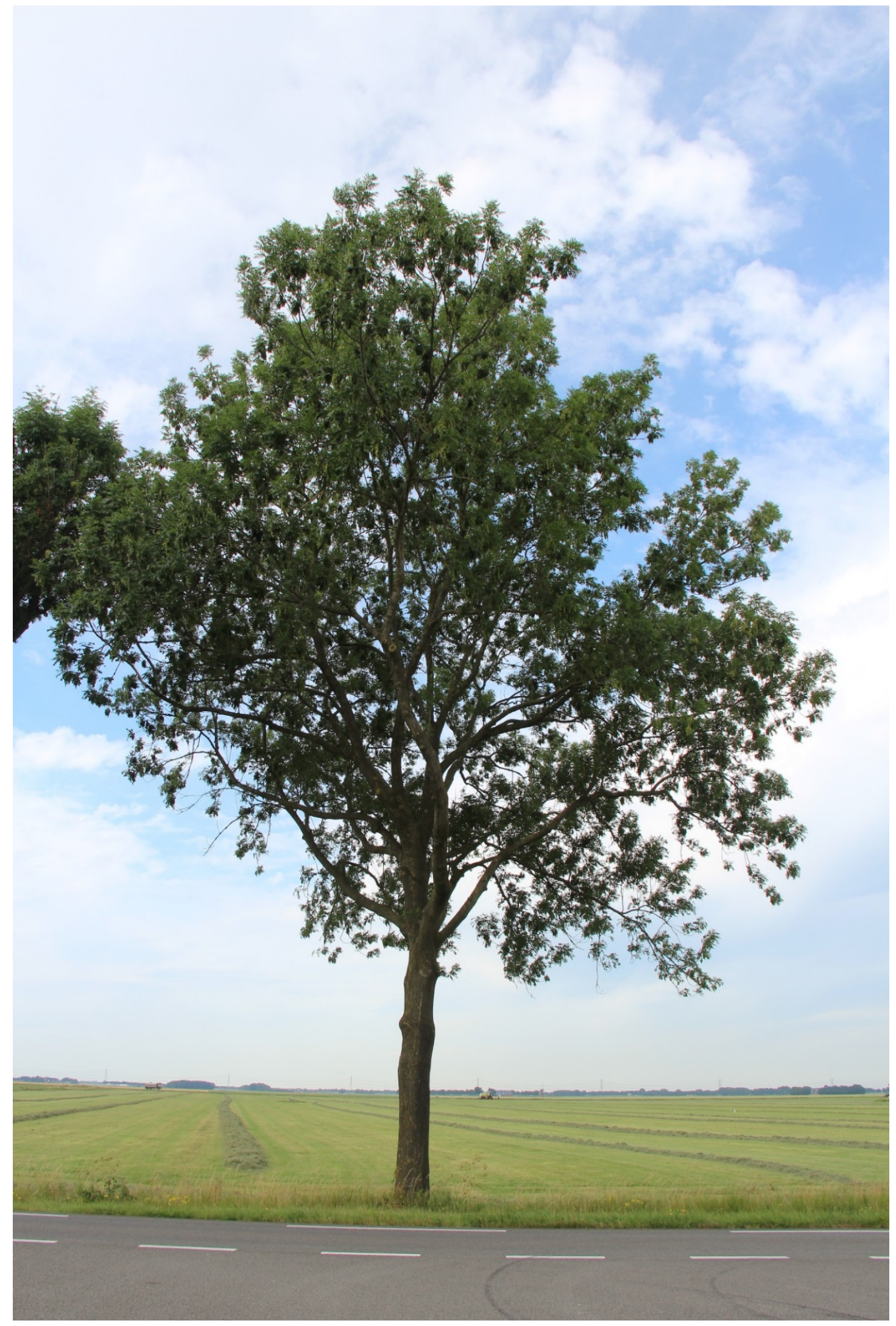

Foto 1a. Geen bladverlies, index 0 (tabel 2)

Geen waterlotvorming, index 0 (tabel 3)

Geen aantasting, ziekteklasse 0 (tabel 4) 


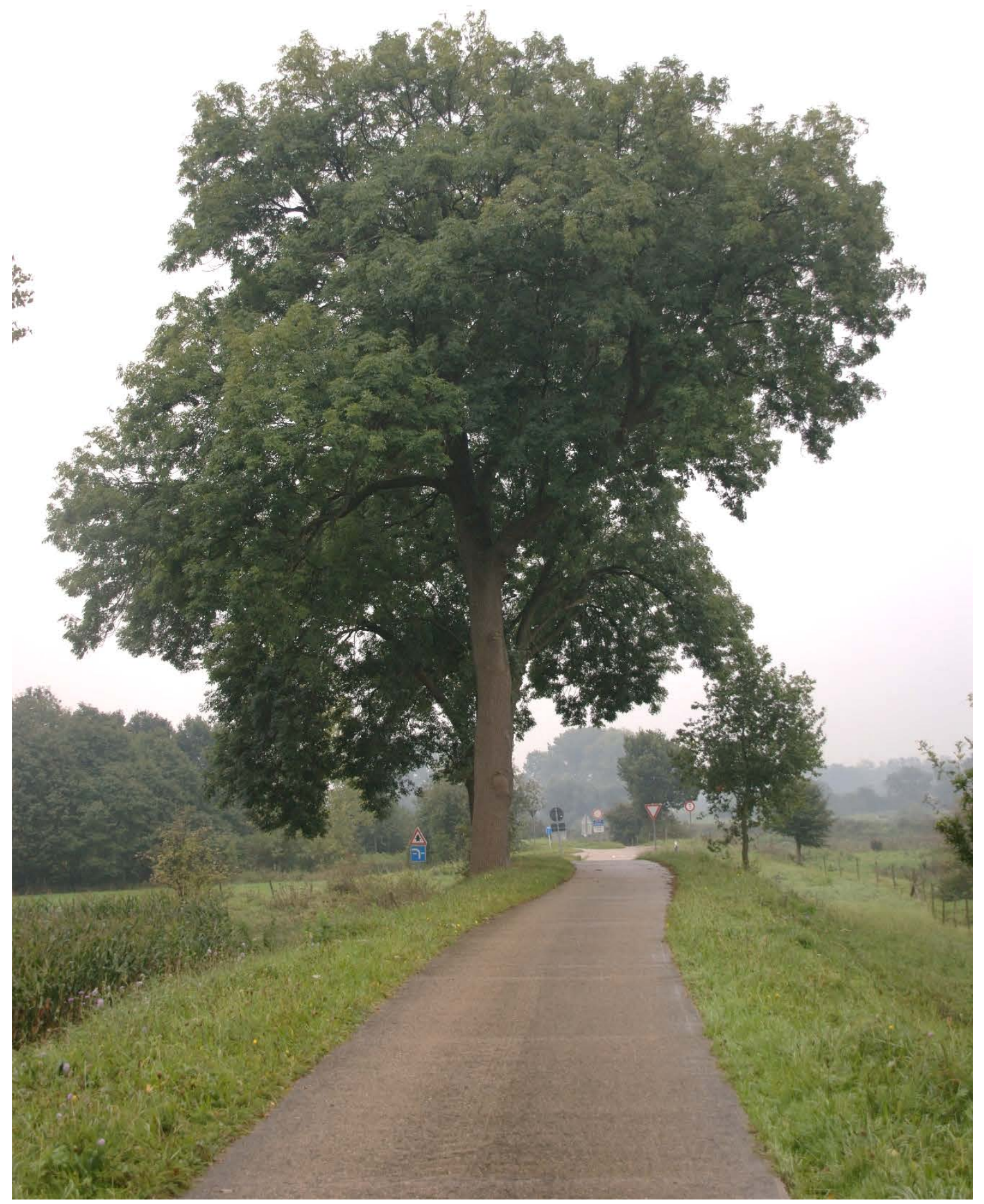

Foto $1 \mathrm{~b}$. Geen bladverlies, index 0 (tabel 2) Geen waterlotvorming, index 0 (tabel 3) Geen aantasting, ziekteklasse 0 (tabel 4 ) 


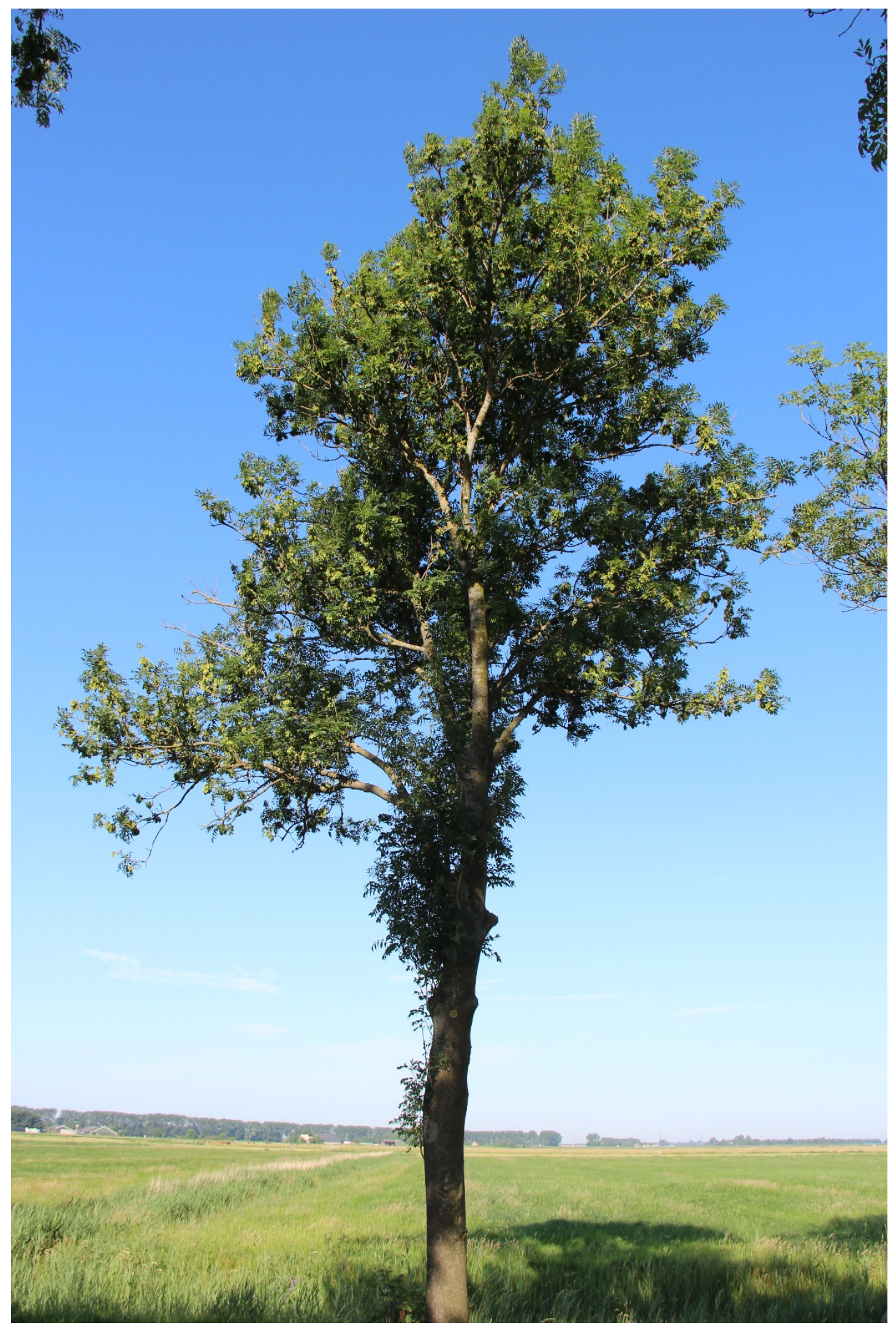

Foto 2 a. $<5 \%$ bladverlies, index 1 (tabel 2 ) 


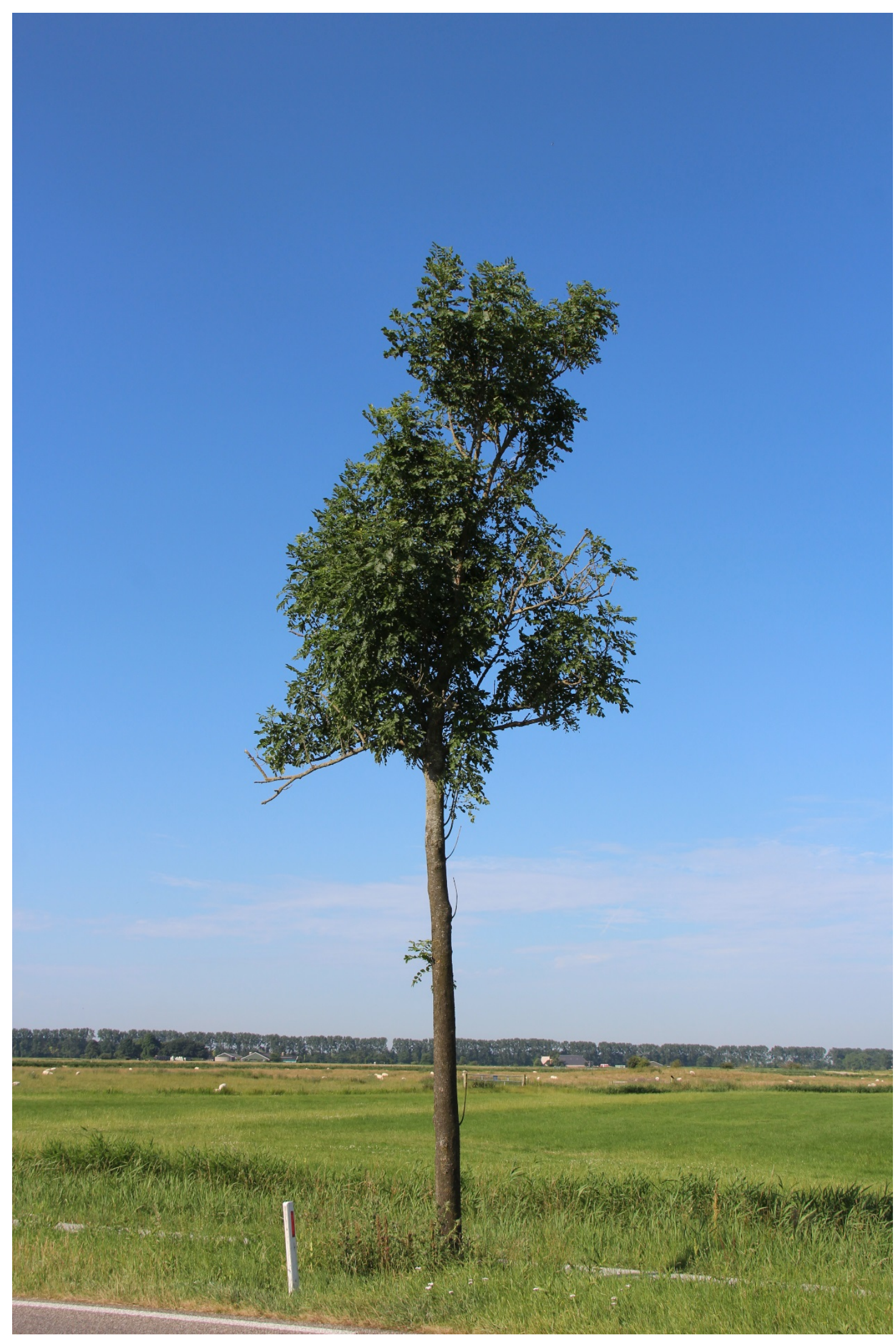

Foto 2 b. $<5 \%$ bladverlies, index 1 (tabel 2 ) 


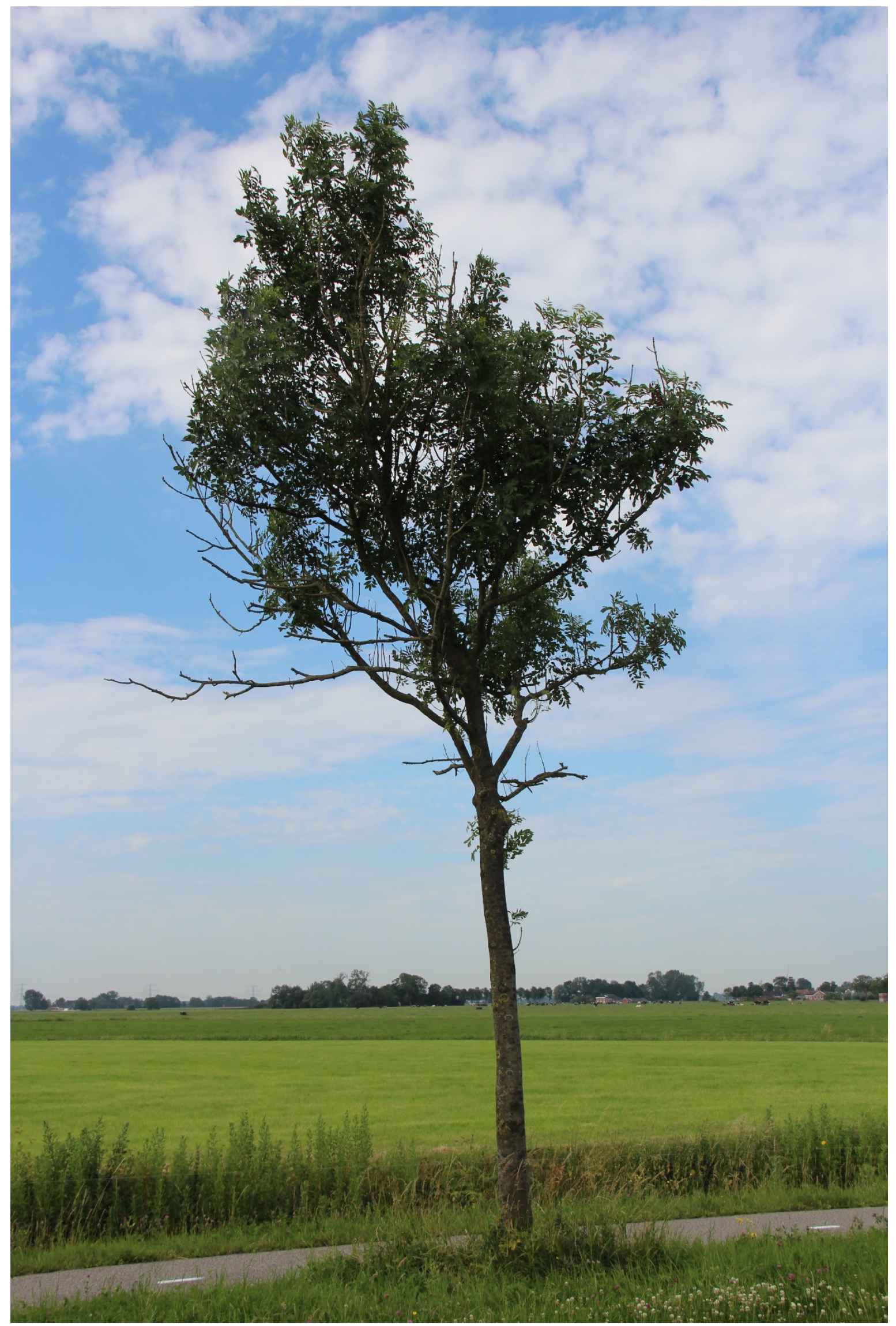

Foto 3a. Bladverlies 5-20\%, index 2 (tabel 2) 


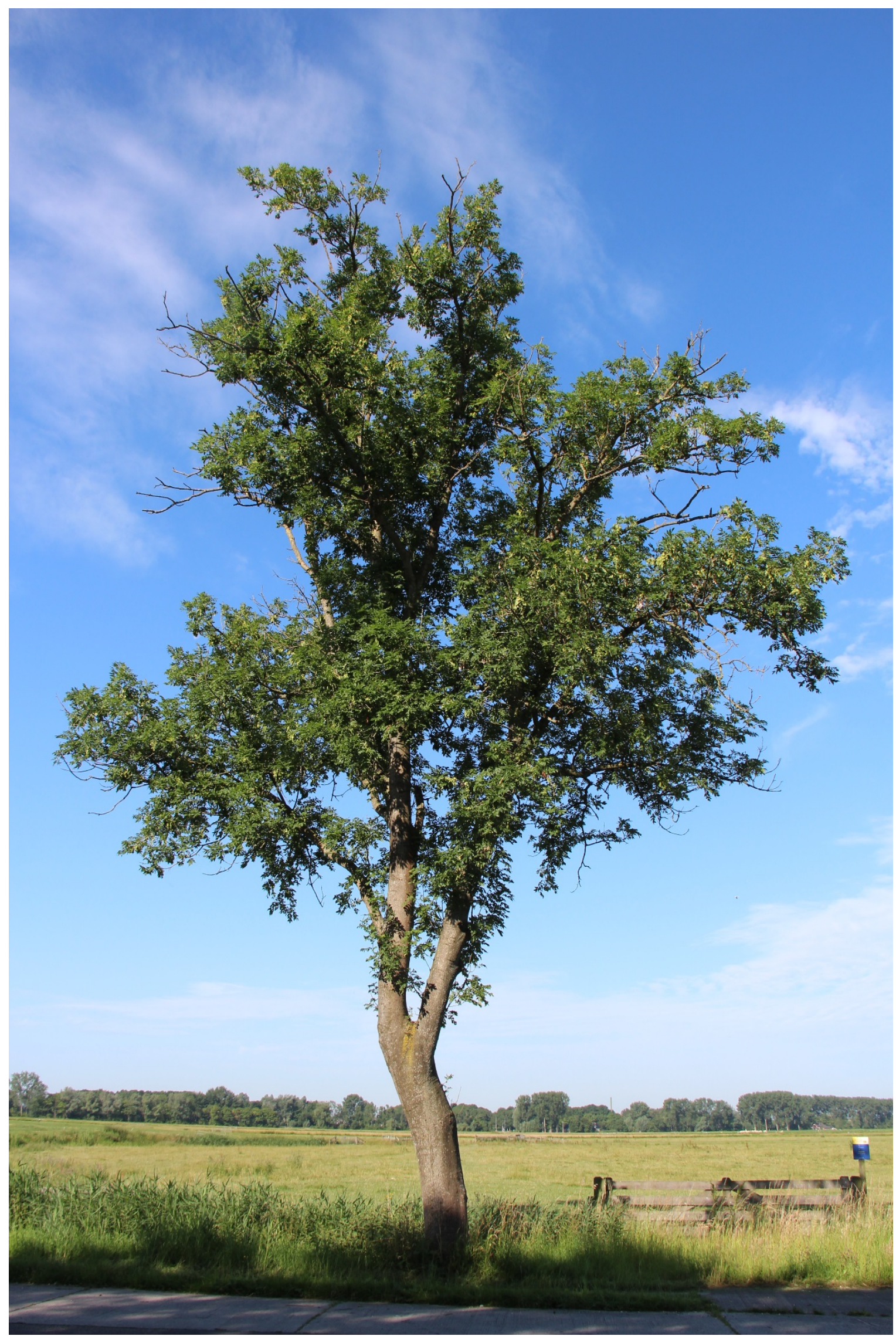

Foto 3b. Bladverlies 5-20\%, index 2 (tabel 2) 


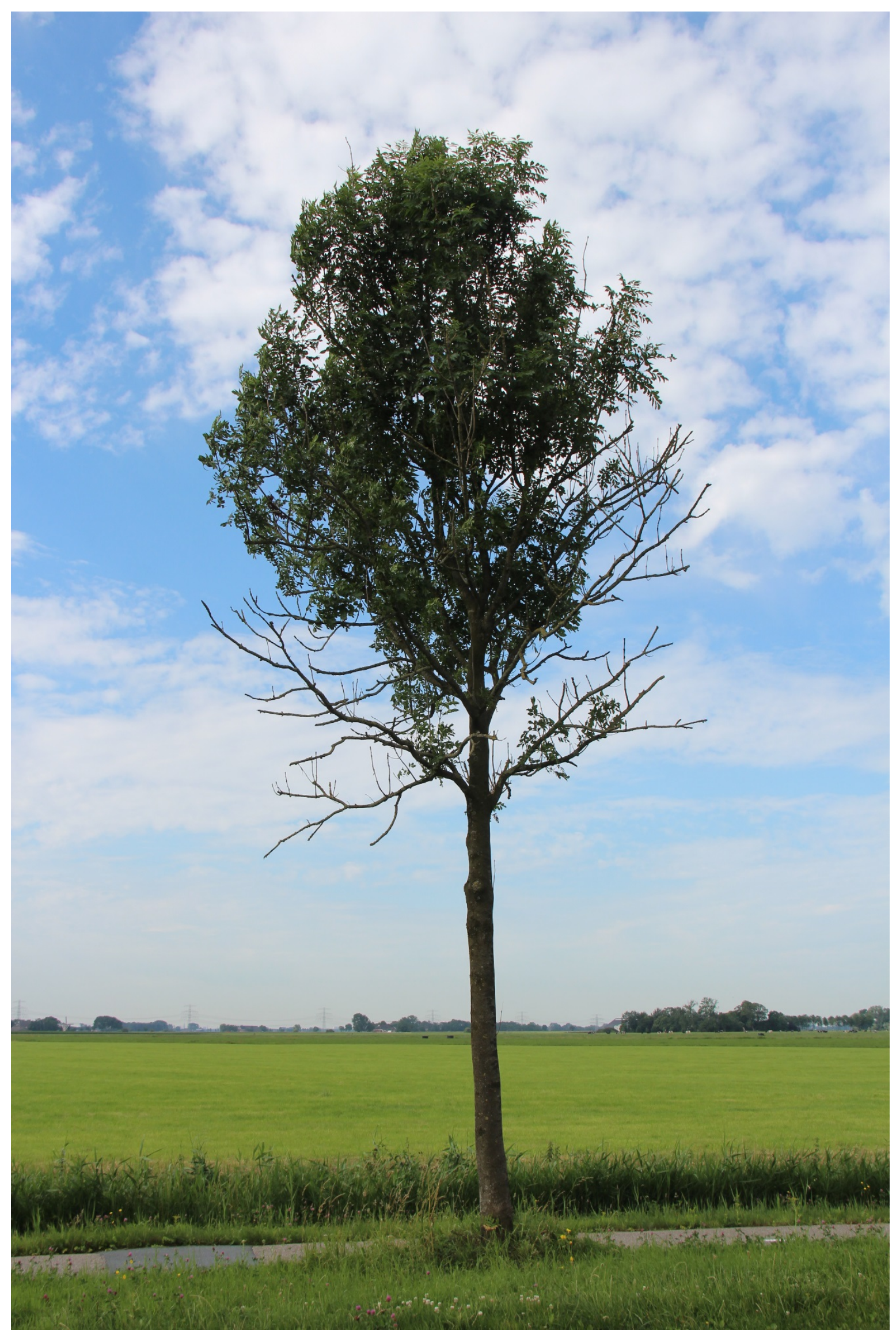

Foto 4 a. Bladverlies $21-50 \%$, index 3 (tabel 2) 


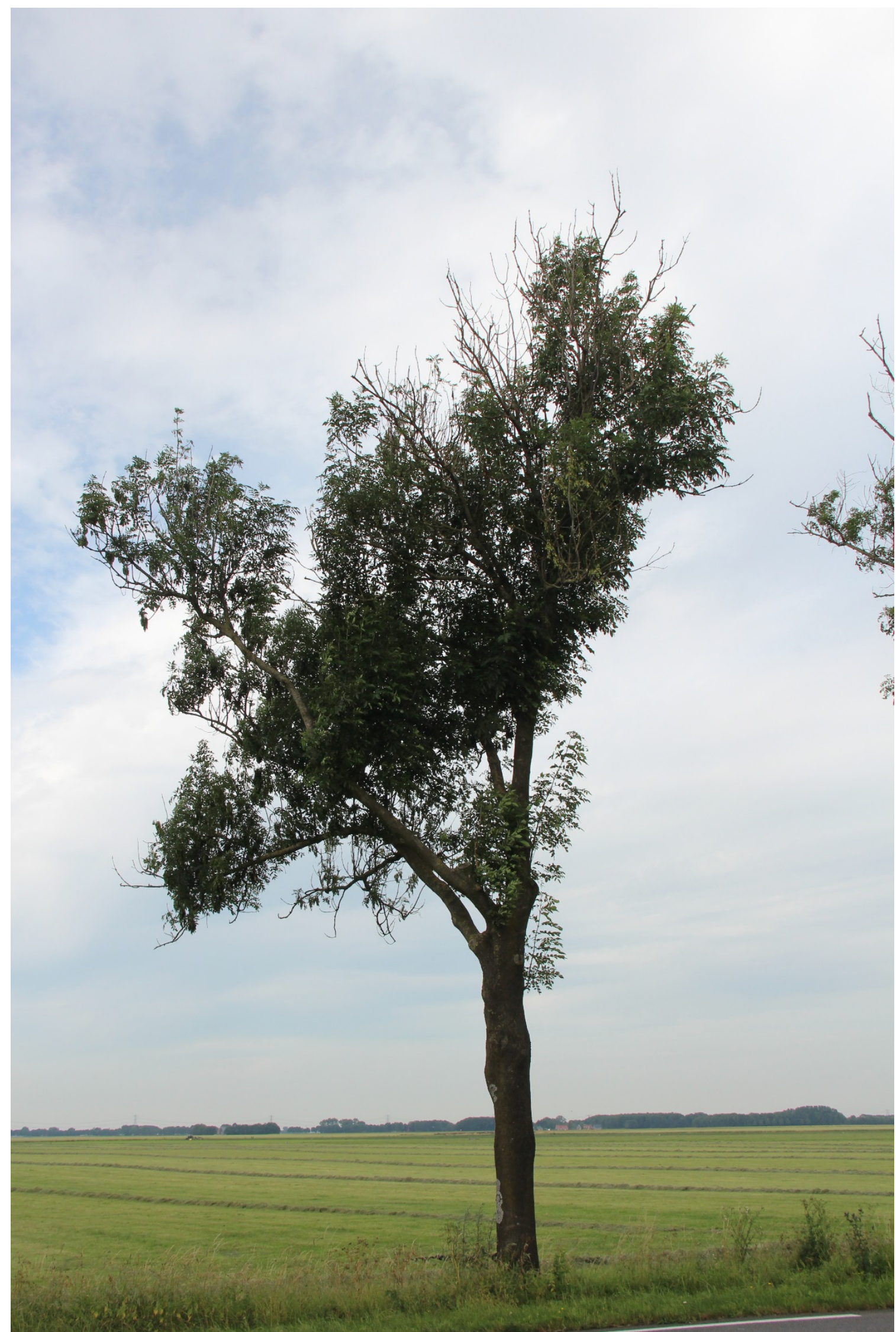

Foto 4b. Bladverlies 21-50\%, index 3 (tabel 2) 


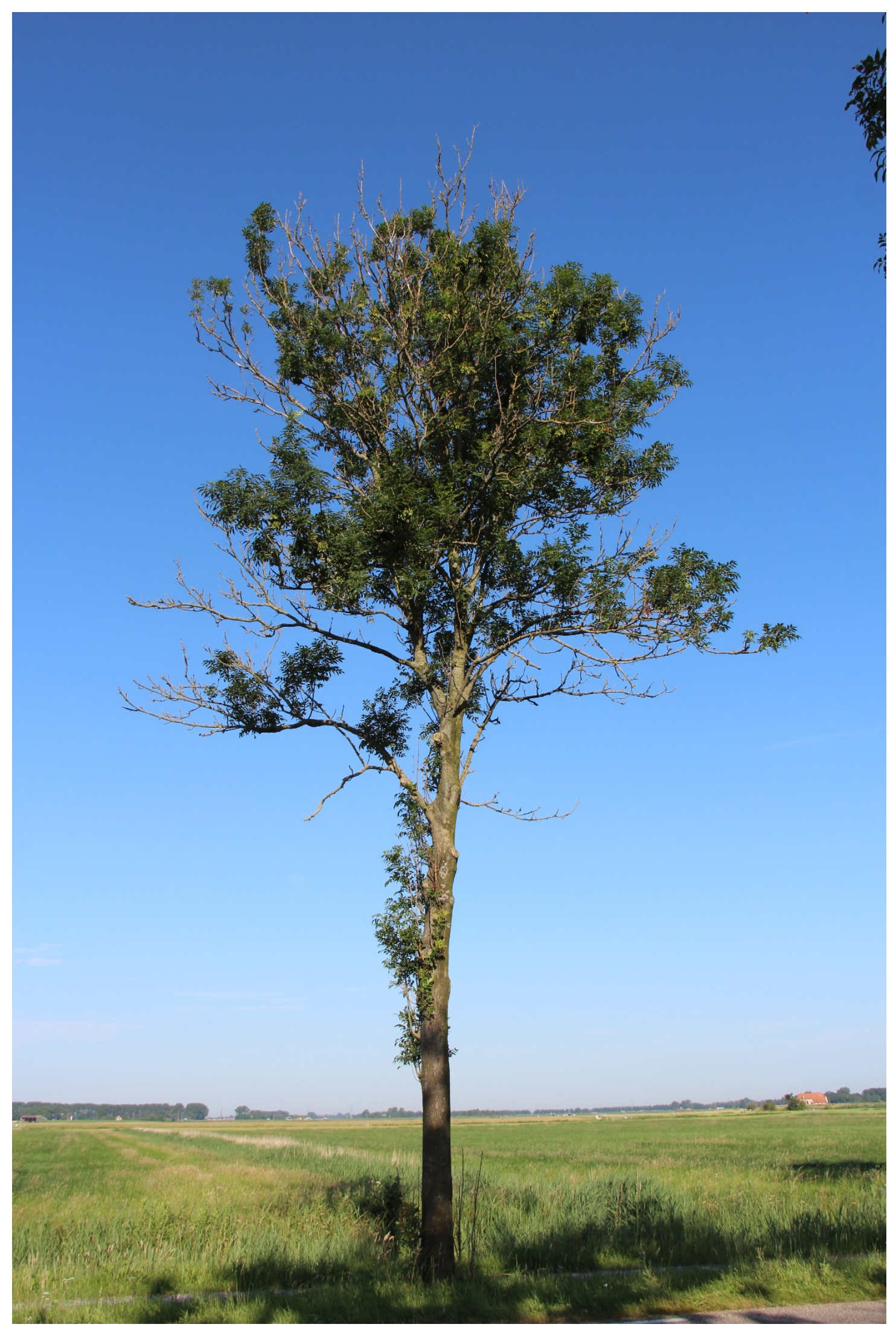

Foto 5a. Bladverlies 51-80\%, index 4 (tabel 2) 


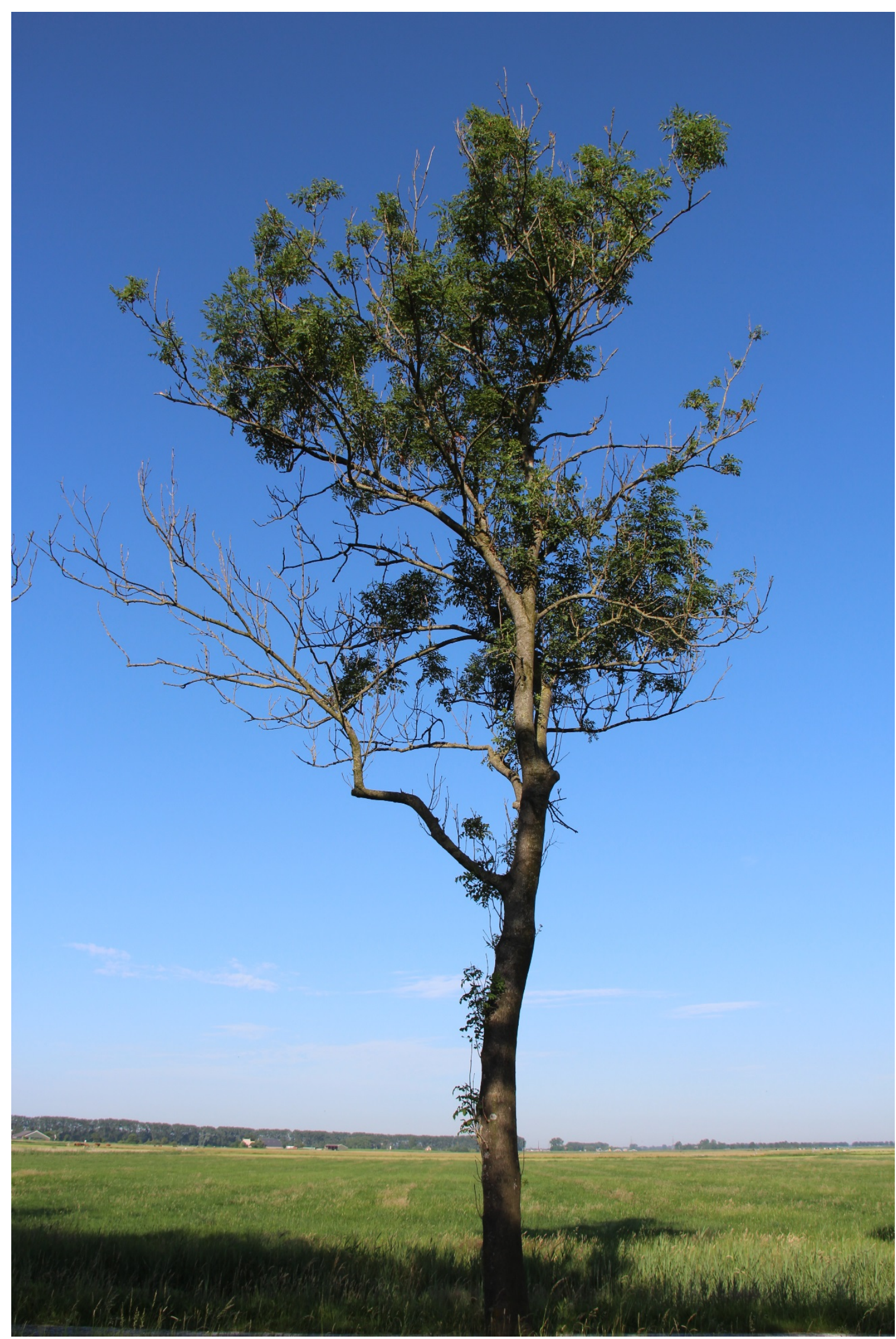

Foto 5 b. Bladverlies $51-80 \%$, index 4 (tabel 2) 


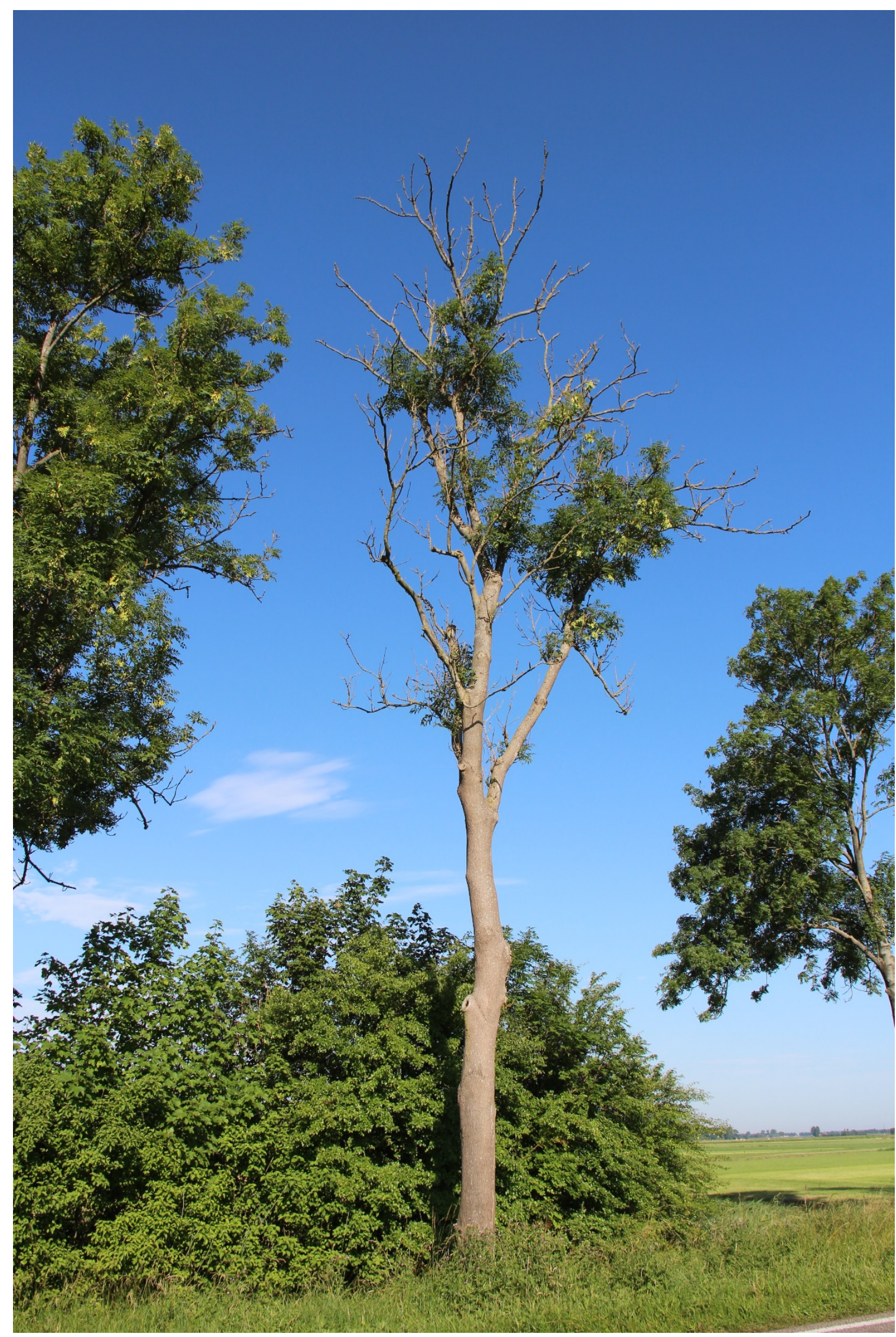

Foto 6a. Bladverlies 81-99\%, index 5 (tabel 2) 


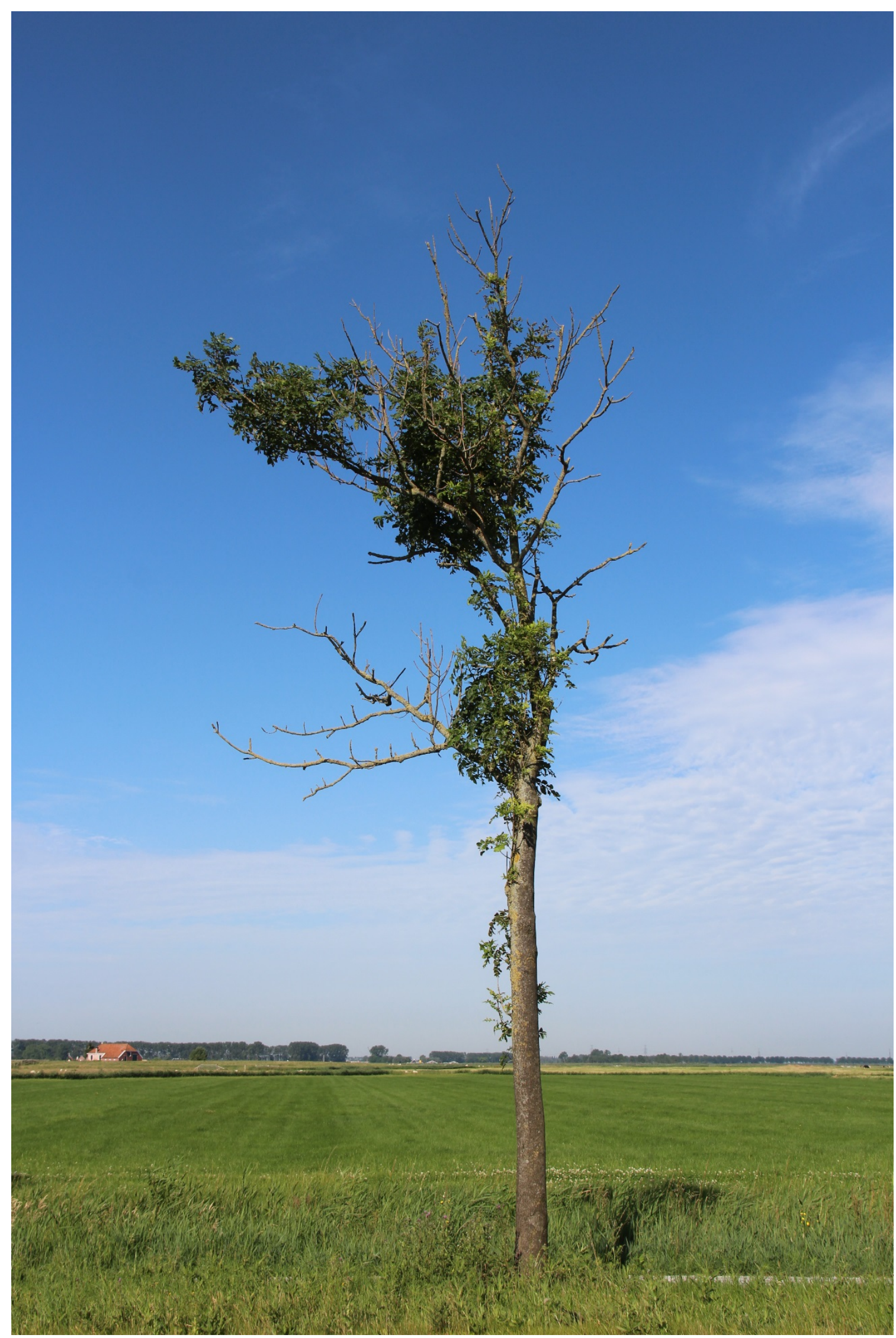

Foto 6b. Bladverlies $81-99 \%$, index 5 (tabel 2) 


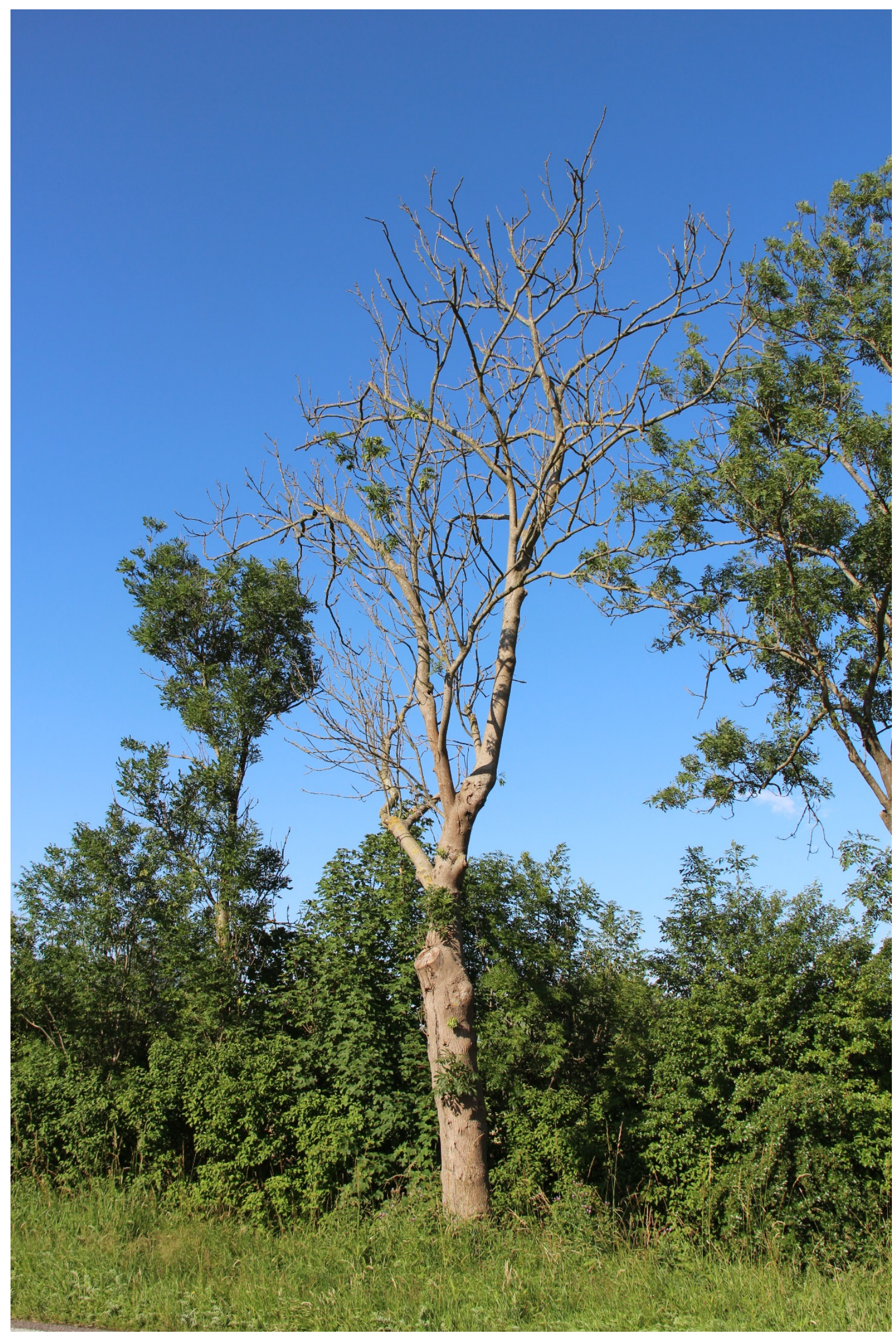

Foto 7 a. Bladverlies $100 \%$, index 6 (tabel 2) 


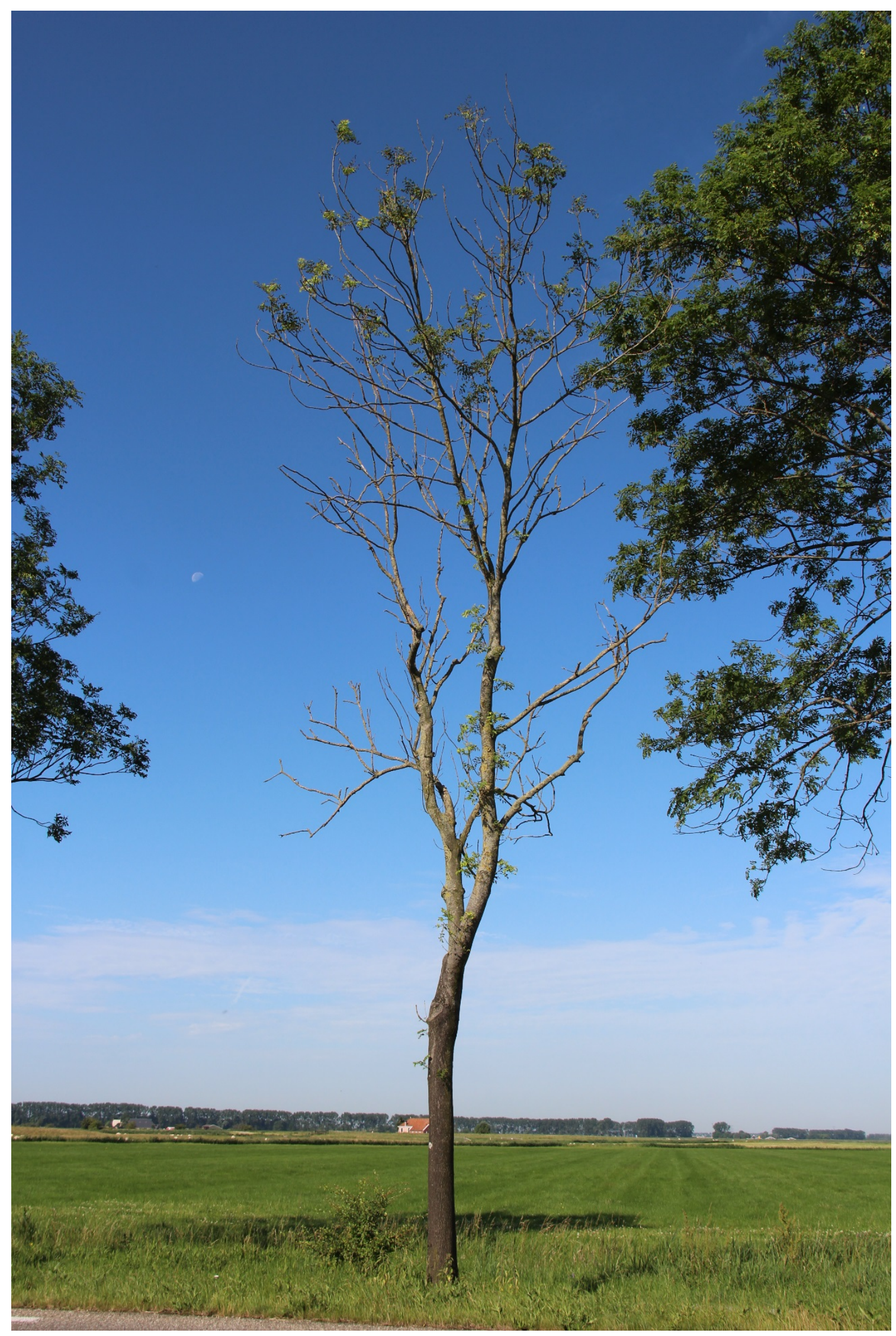

Foto $7 \mathrm{~b}$. Bladverlies $100 \%$, index 6 (tabel 2) 


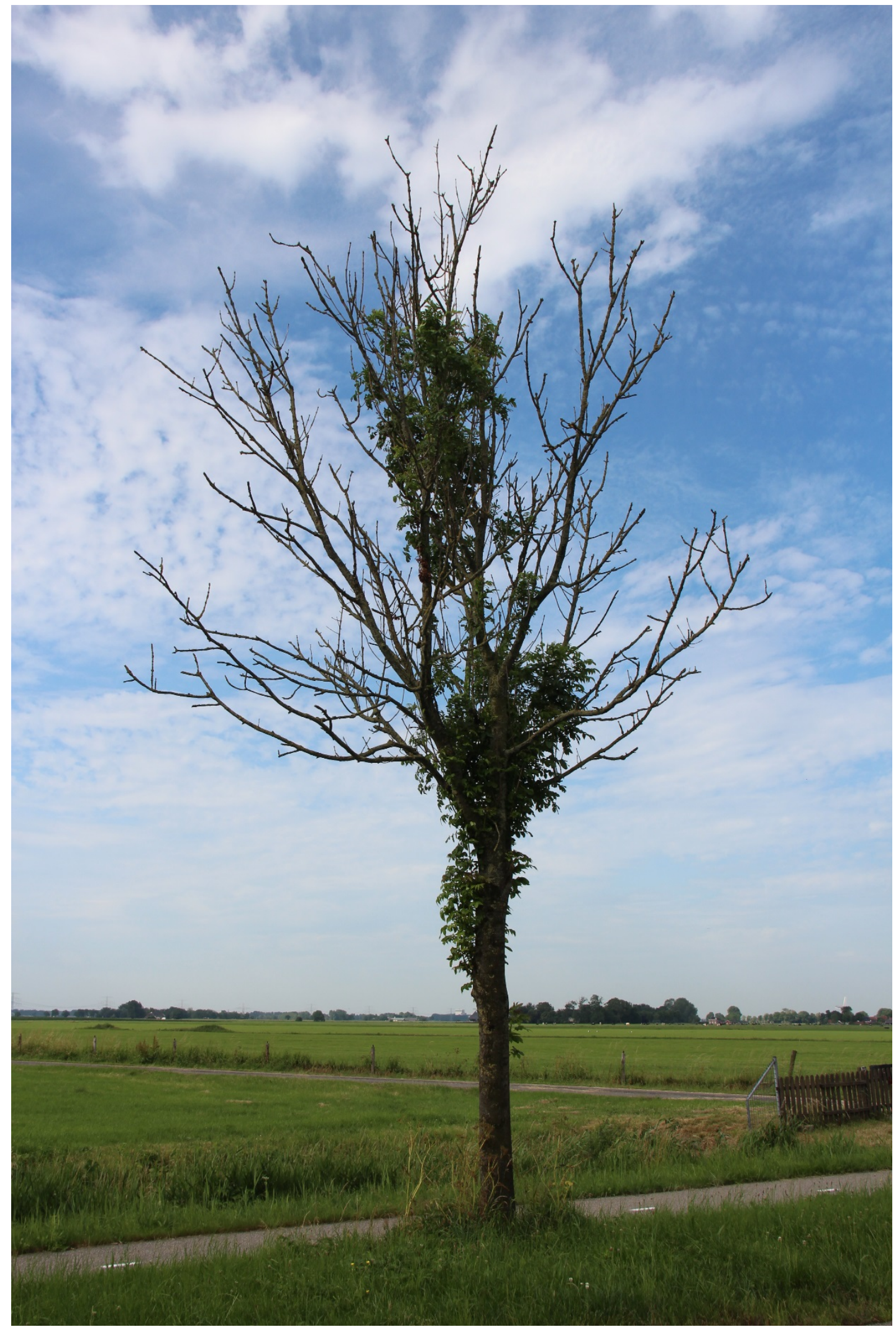

Foto 8a. Bladpercentage door waterlotvorming is minder dan $5 \%$, index 1 (tabel 3 ) 


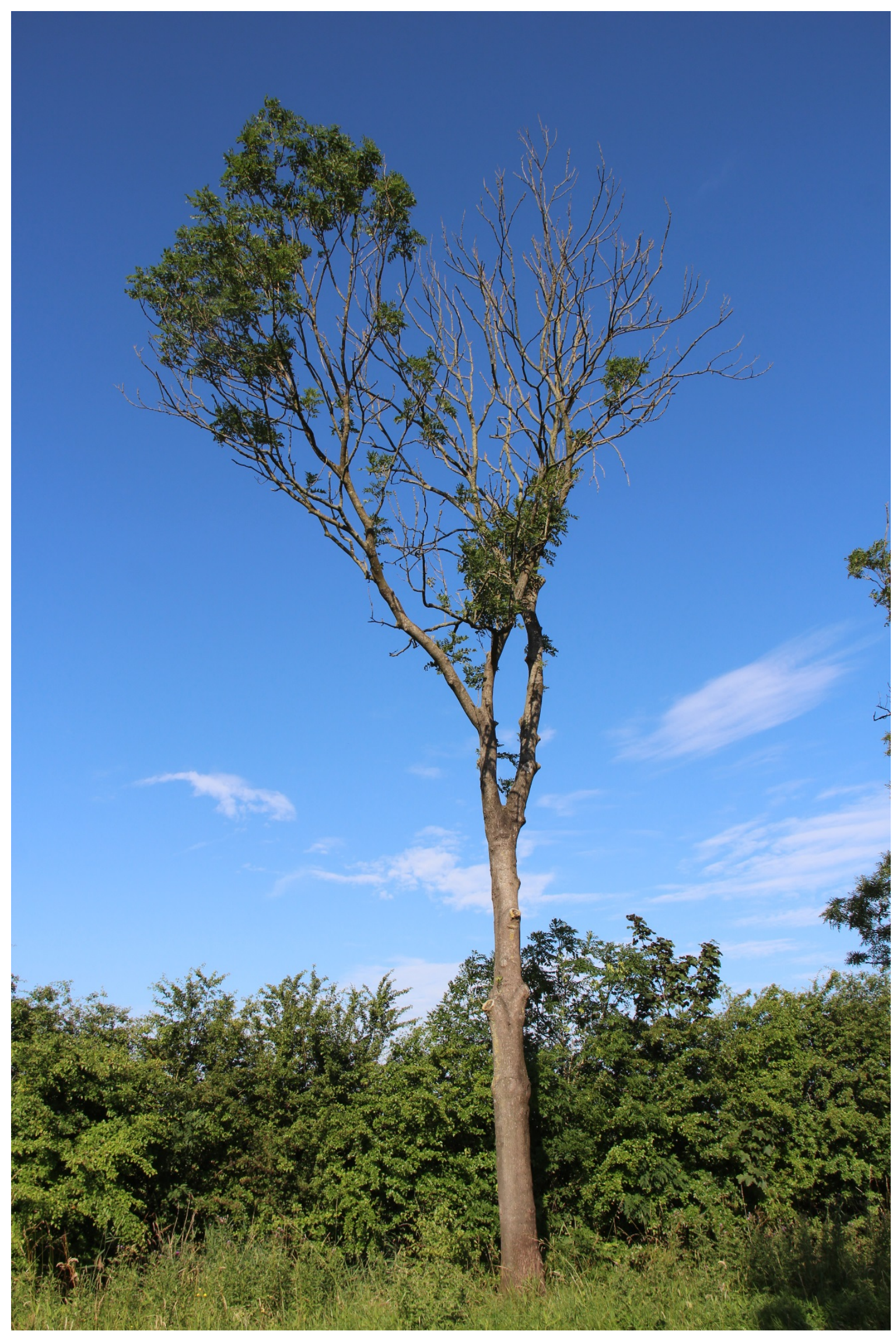

Foto 8 b. Bladpercentage door waterlotvorming is $<5 \%$, index 1 (tabel 3 ) 




Foto 9a. Bladpercentage door waterlotvorming is $5-20 \%$, index 2 (tabel 3) 


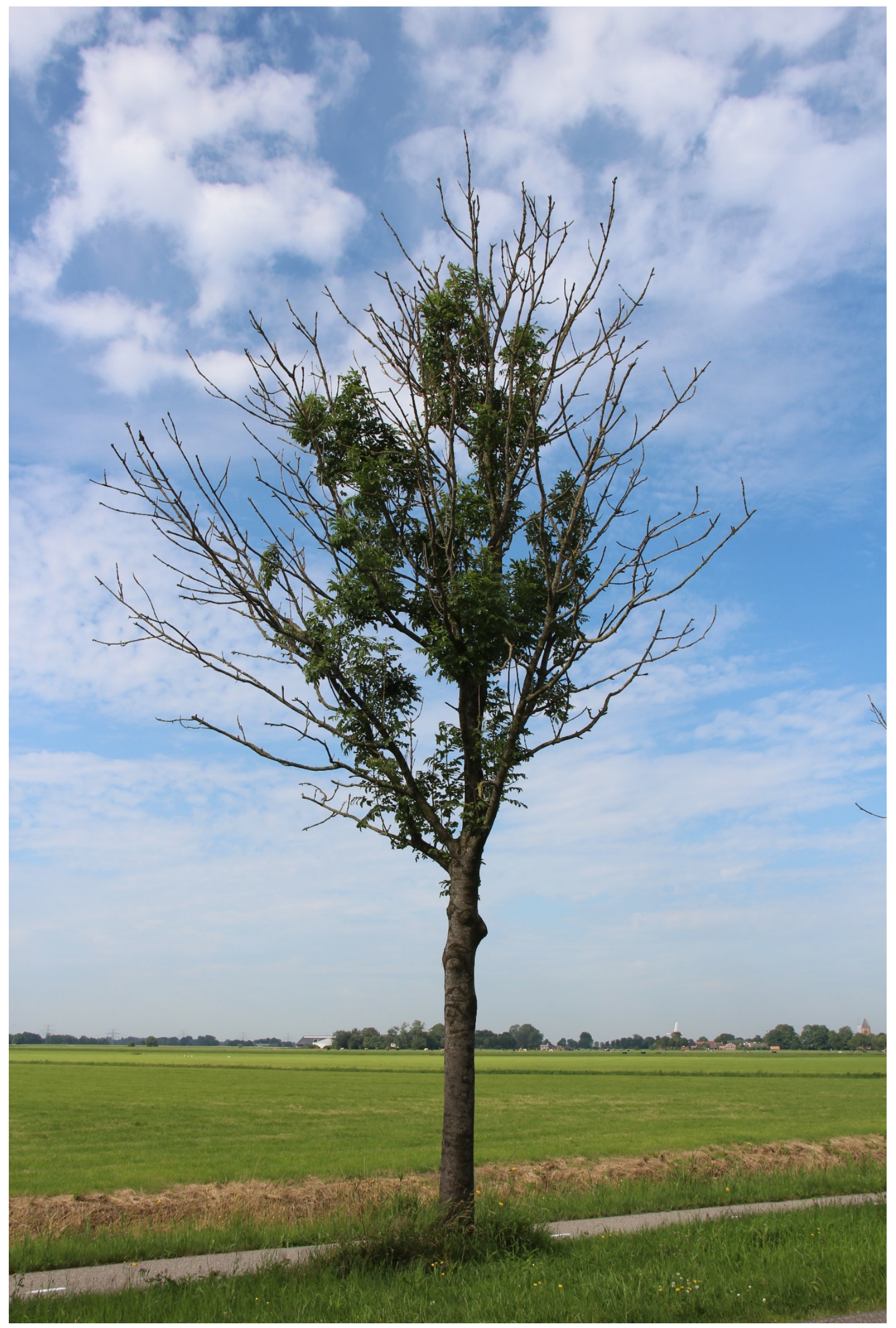

Foto 9b. Bladpercentage door waterlotvorming is $5-20 \%$, index 2 (tabel 3 ) 


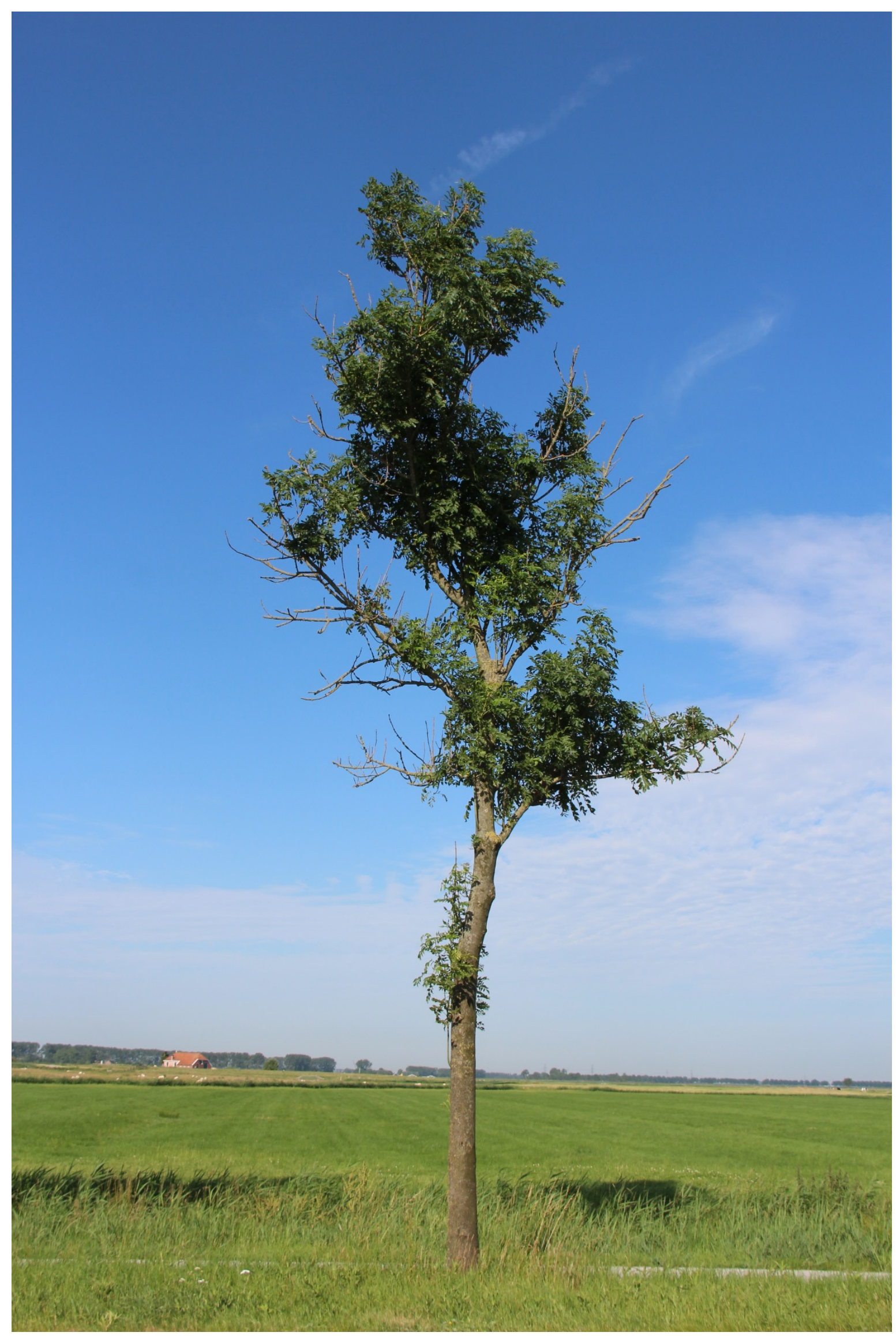

Foto 10 a. Bladpercentage door waterlotvorming is $21-50 \%$, index 3 (tabel 3 ) 


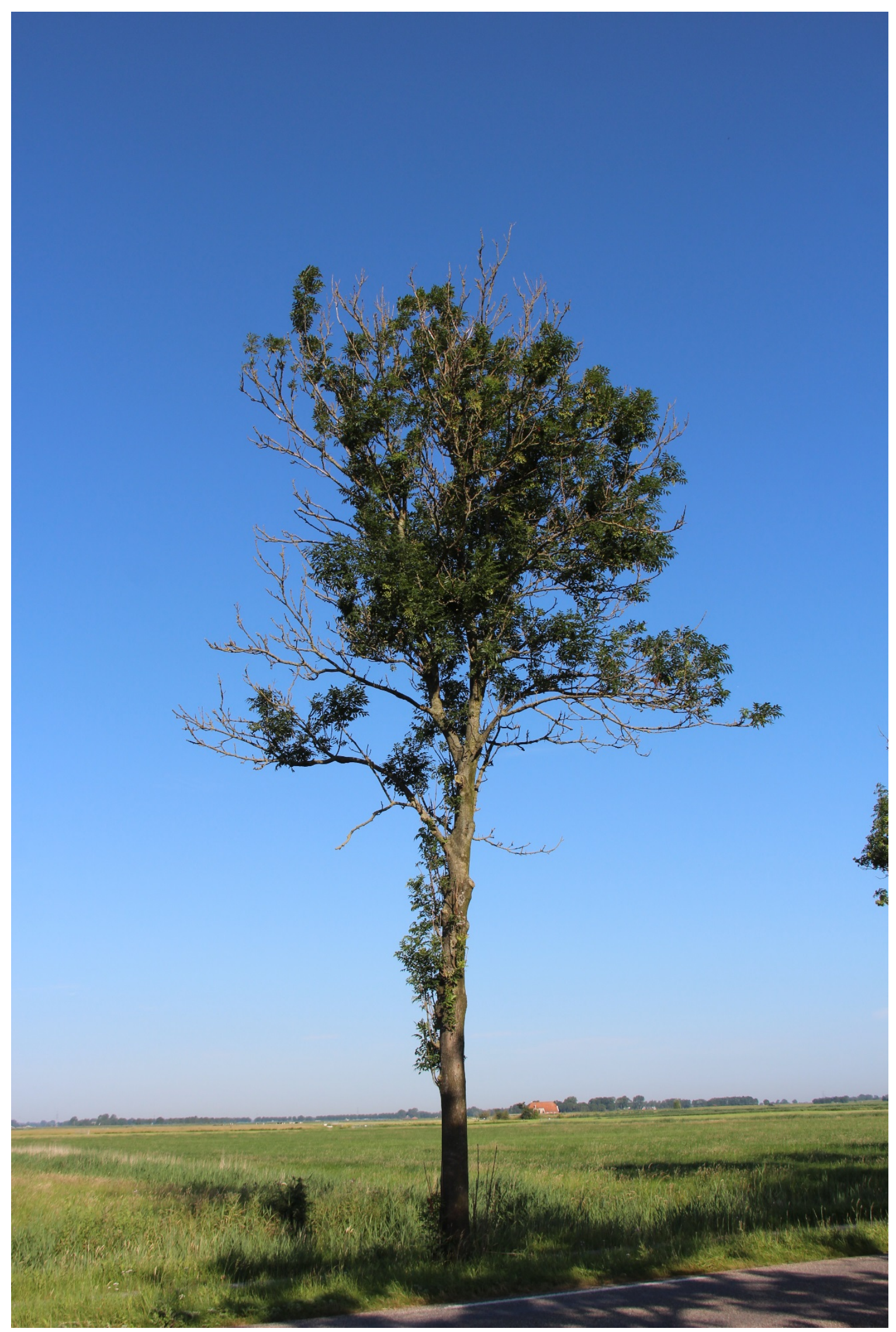

Foto $10 \mathrm{~b}$. Bladpercentage door waterlotvorming is $21-50 \%$, index 3 (tabel 3 ) 


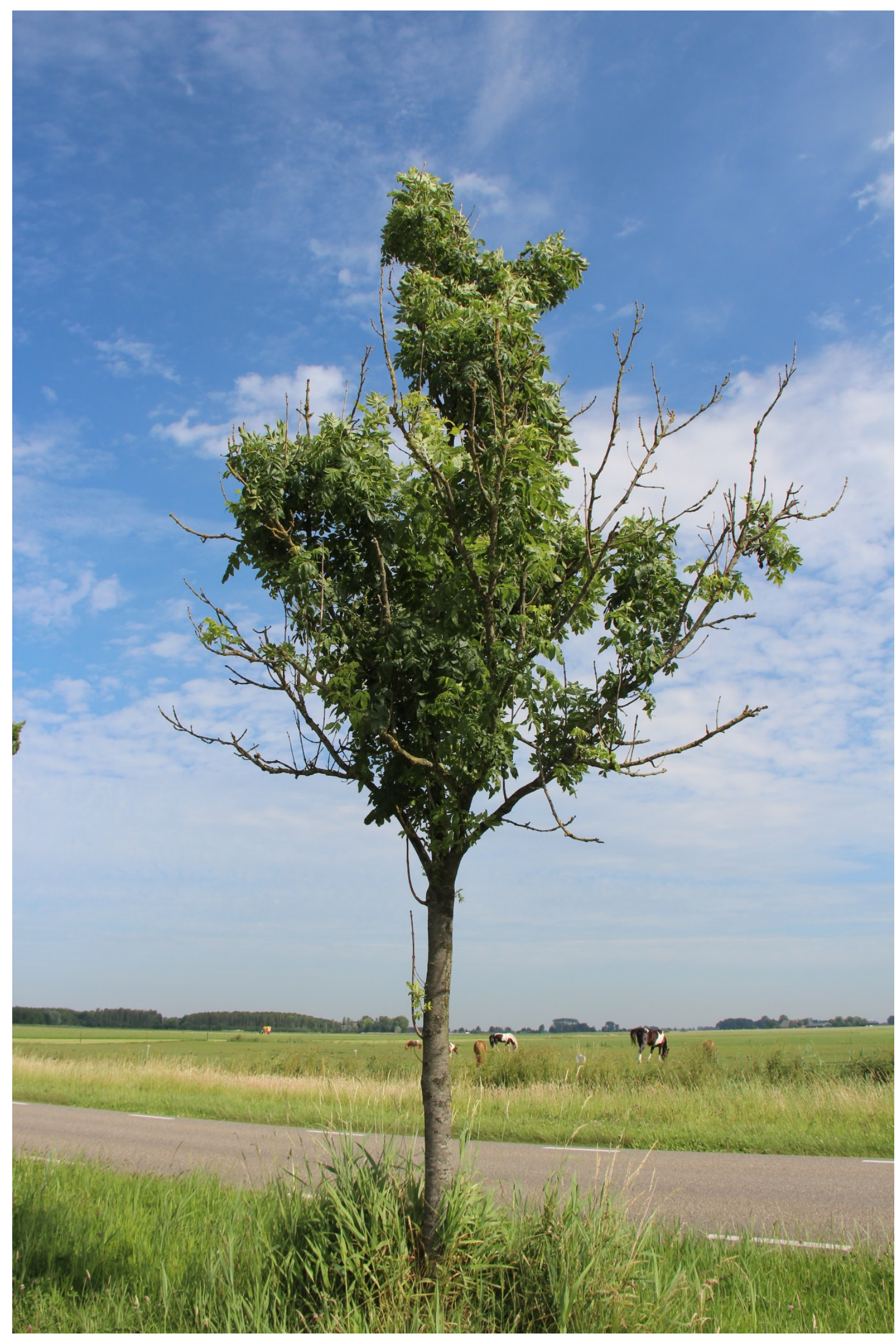

Foto 11 a. Bladpercentage door waterlotvorming is $51-80 \%$, index 4 (tabel 3 ) 


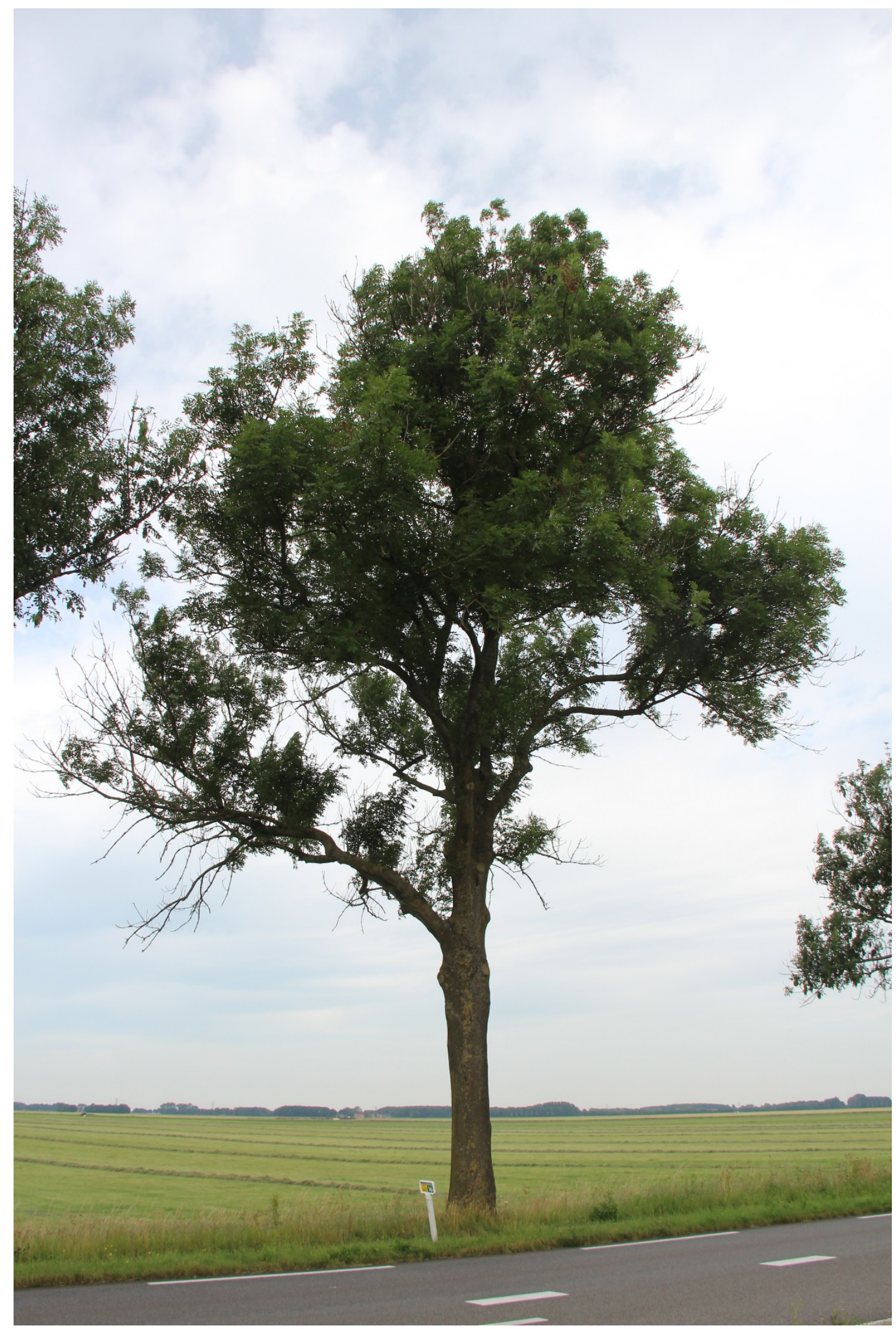

Foto 11 b. Bladpercentage door waterlotvorming is $51-80 \%$, index 4 (tabel 3 ) 


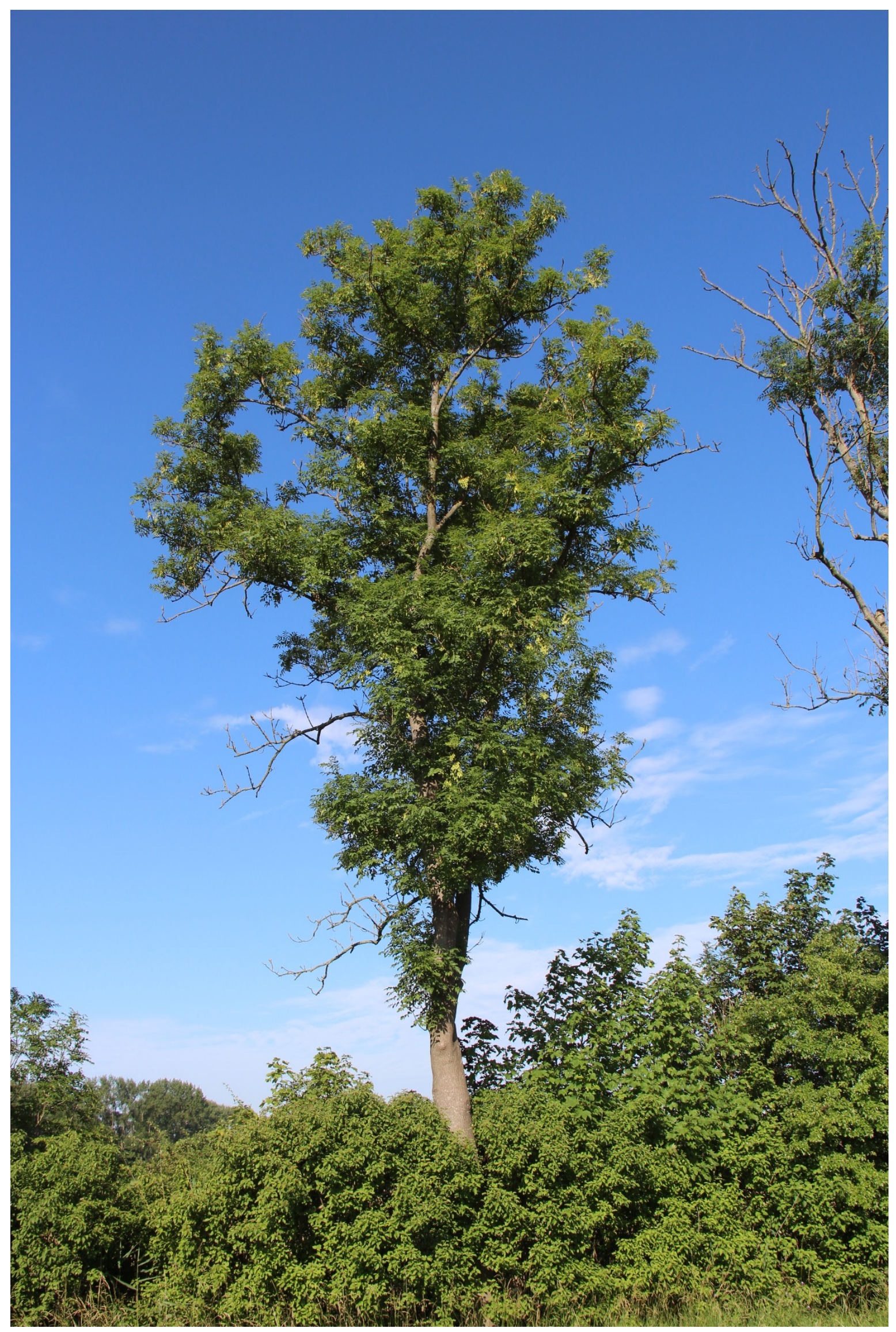

Foto 12 a. Bladpercentage door waterlotvorming is $81-99 \%$, index 5 (tabel 3 ) 


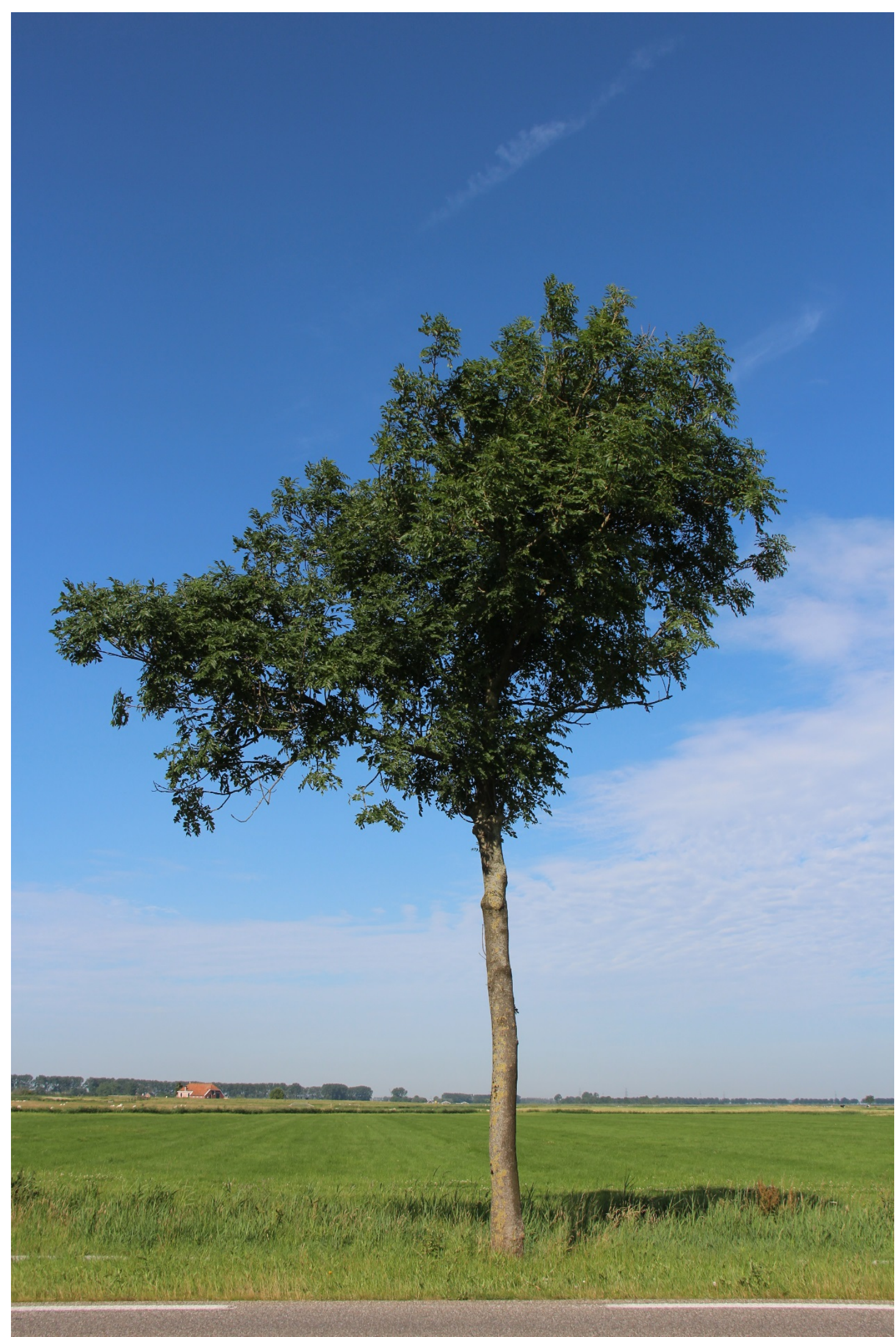

Foto 12 b. Bladpercentage door waterlotvorming is $81-99 \%$, index 5 (tabel 3) 


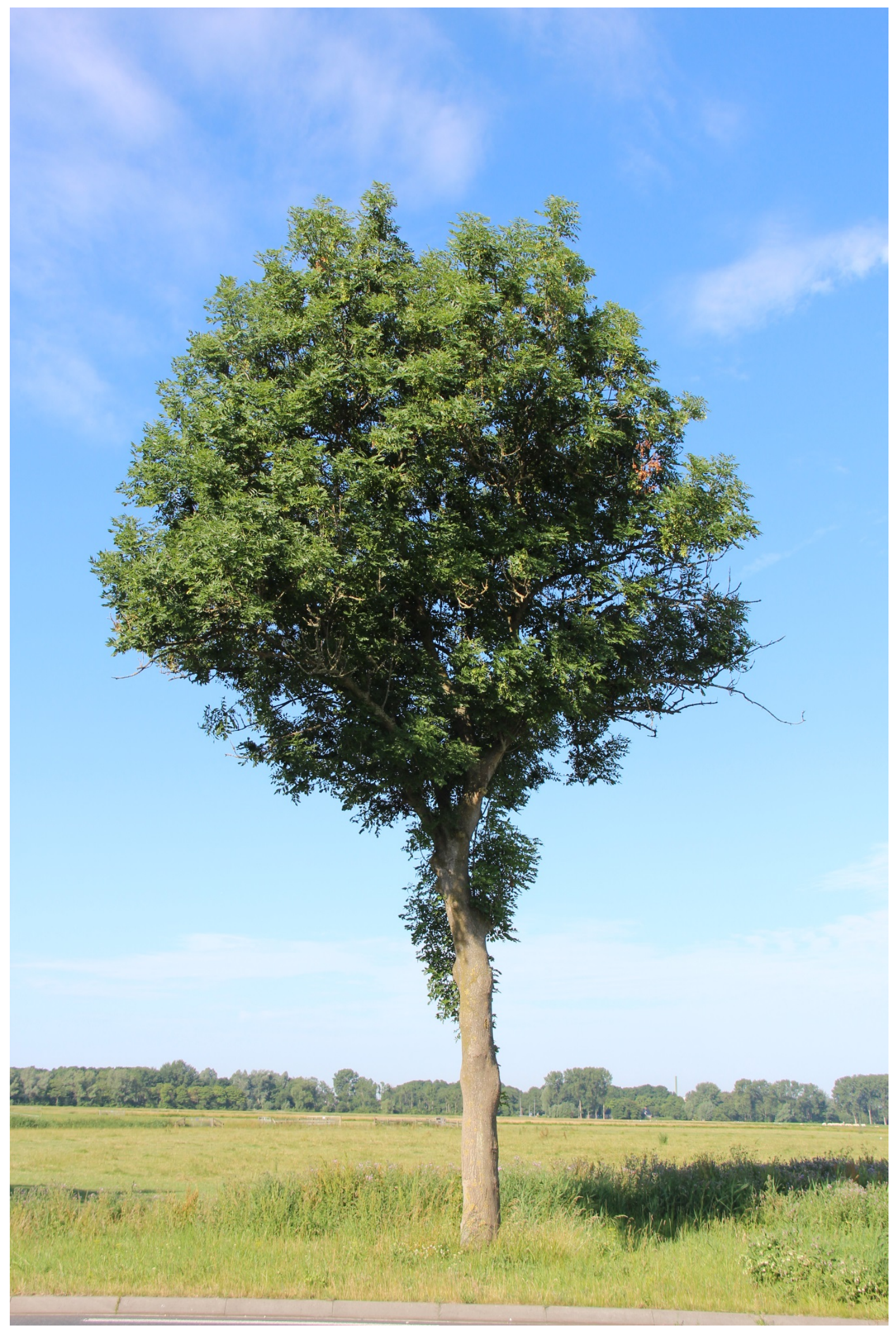

Foto 13a. Bladpercentage door waterlotvorming is $100 \%$, index 6 (tabel 3) 


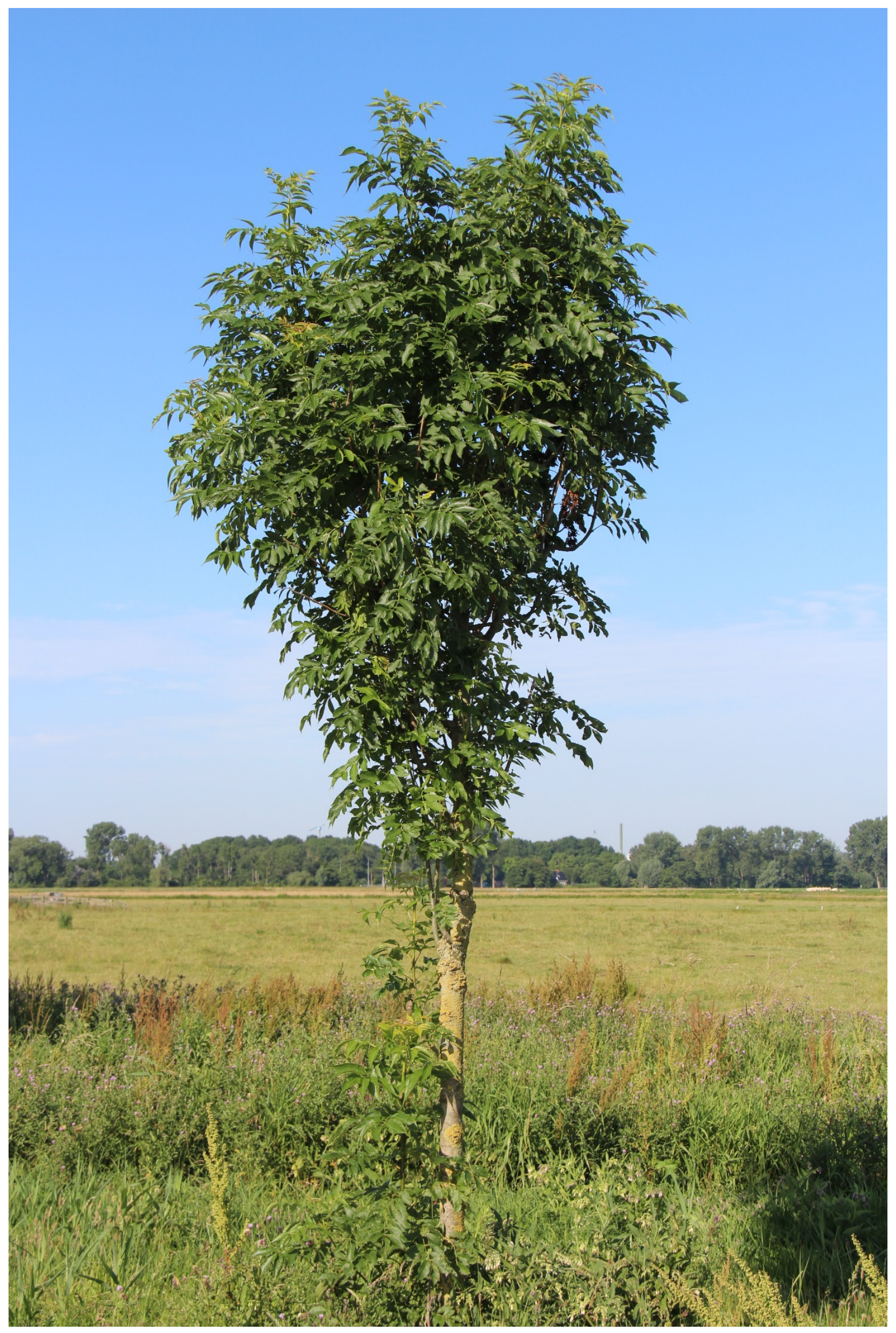

Foto 13 b. Bladpercentage door waterlotvorming is $100 \%$, index 6 (tabel 3) 


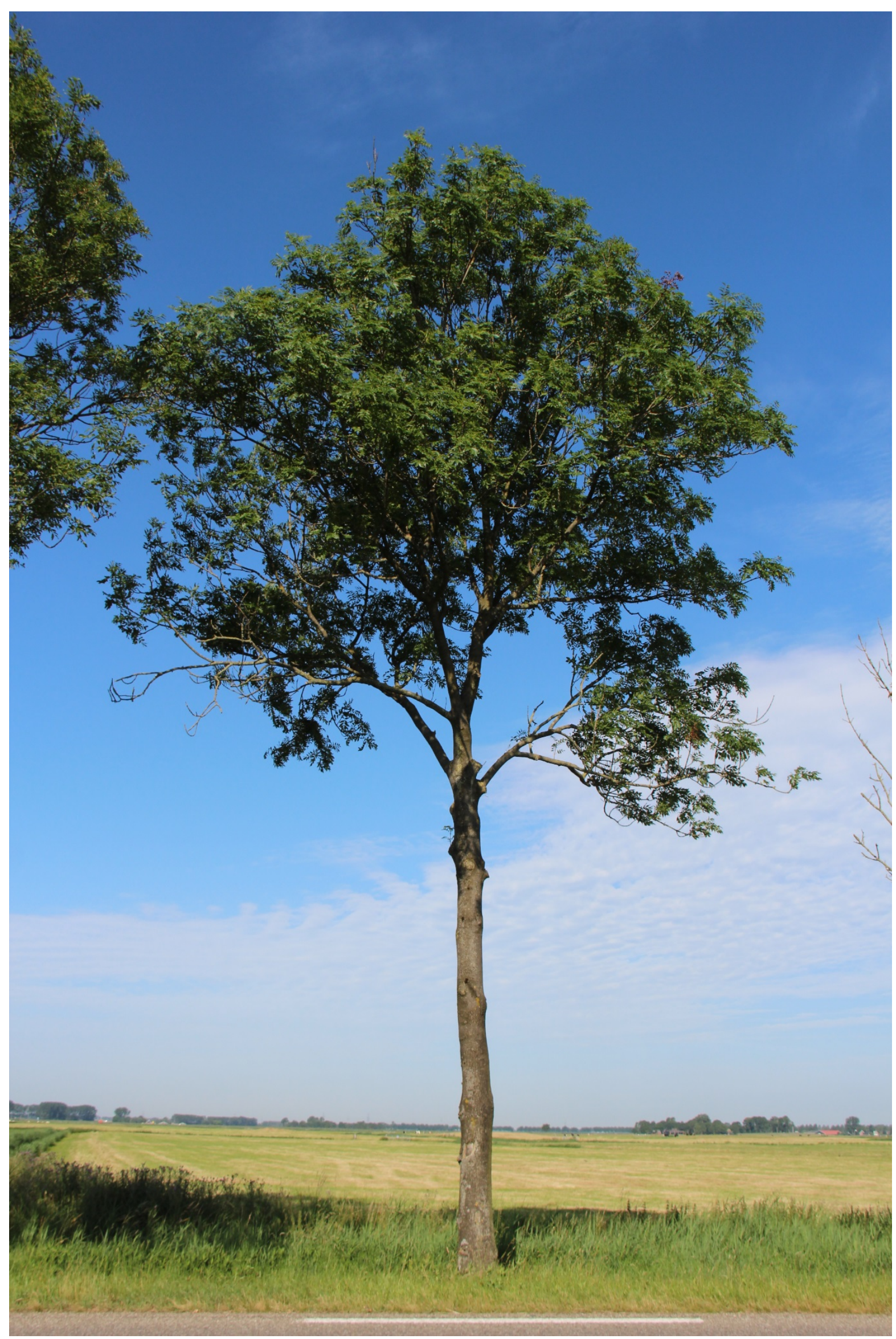

Foto 14a. Lichte aantasting, ziekteklasse 1 (tabel 4) 


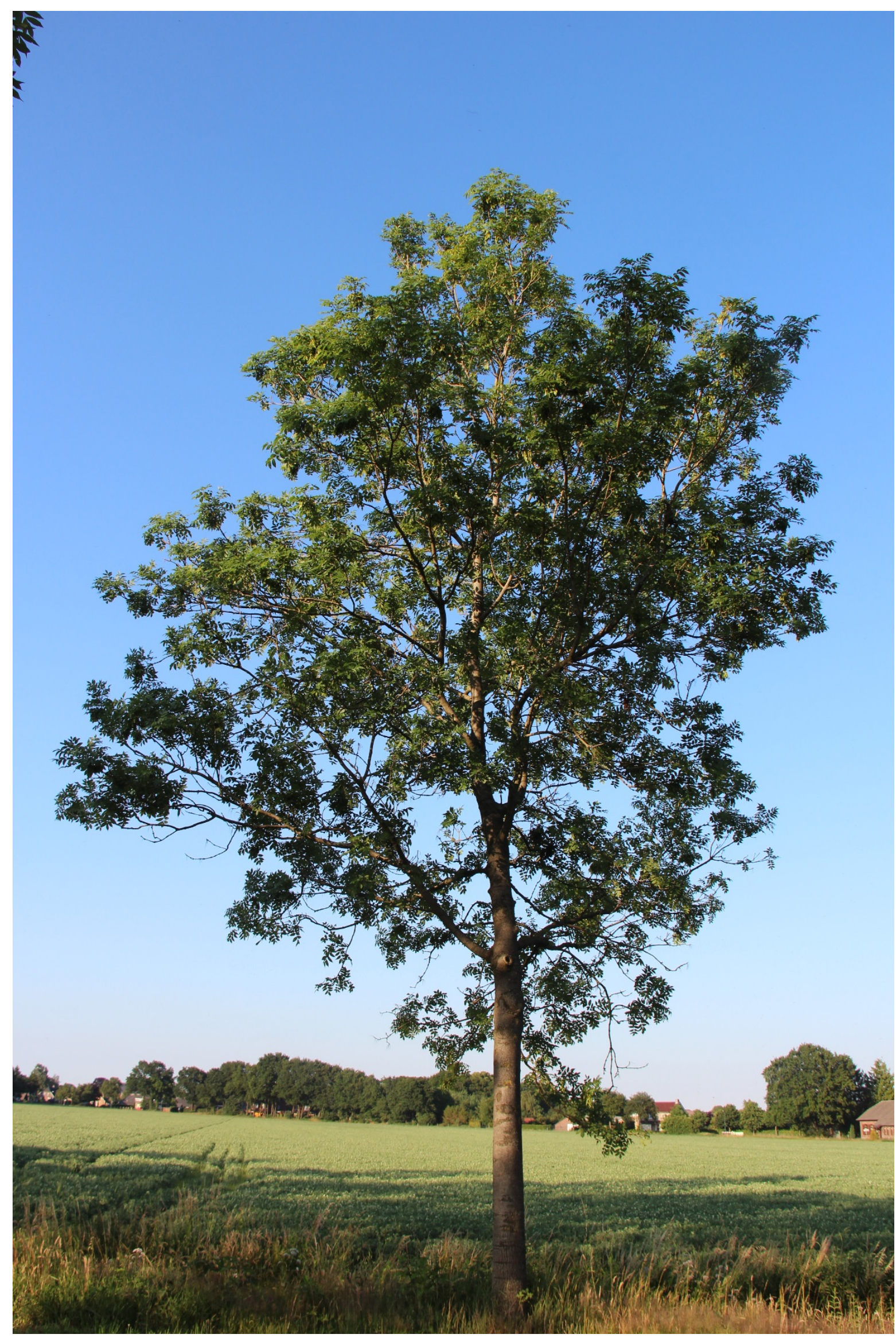

Foto 14b. Lichte aantasting, ziekteklasse 1 (tabel 4) 


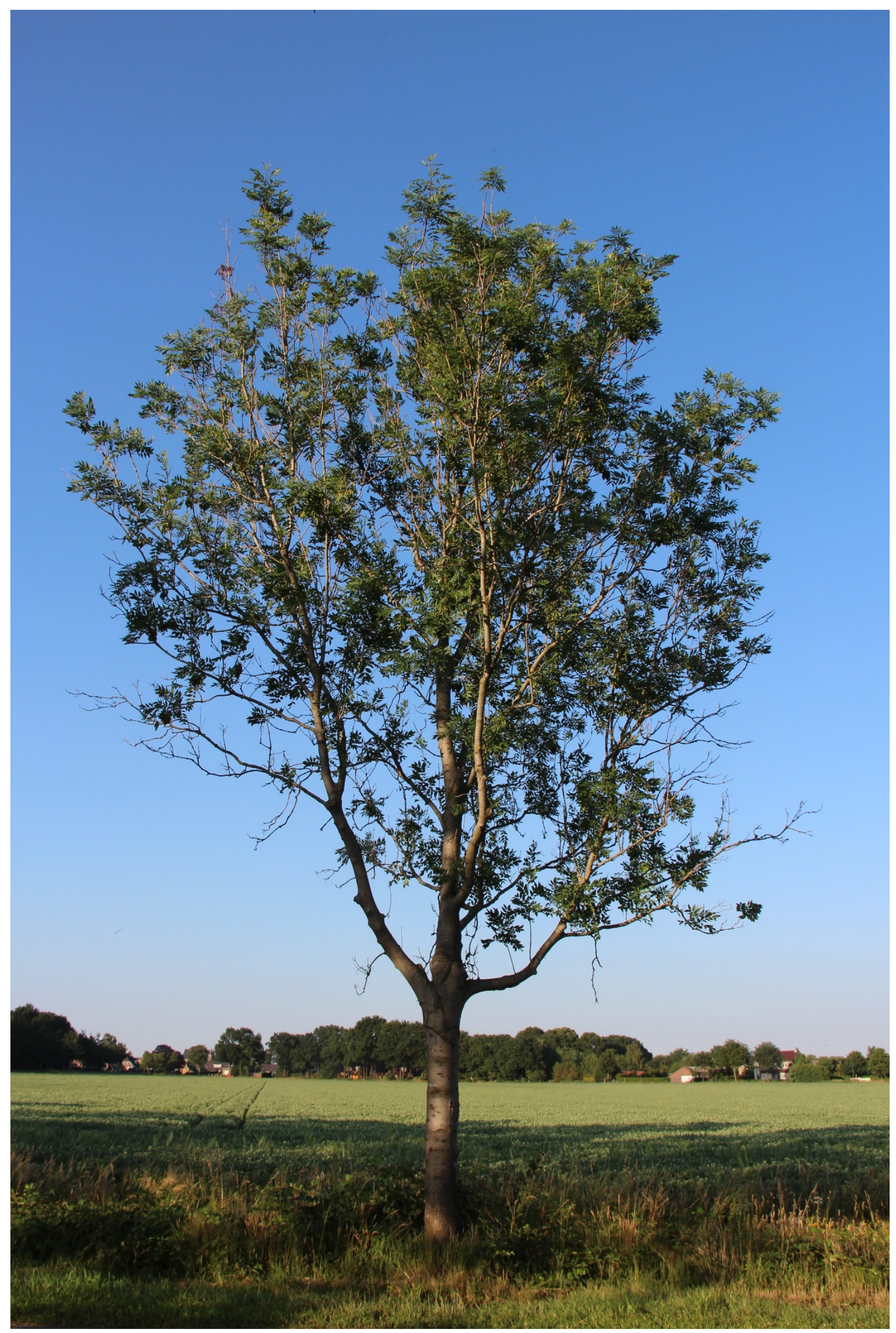

Foto 15a. Matige aantasting, ziekteklasse 2 (tabel 4) 


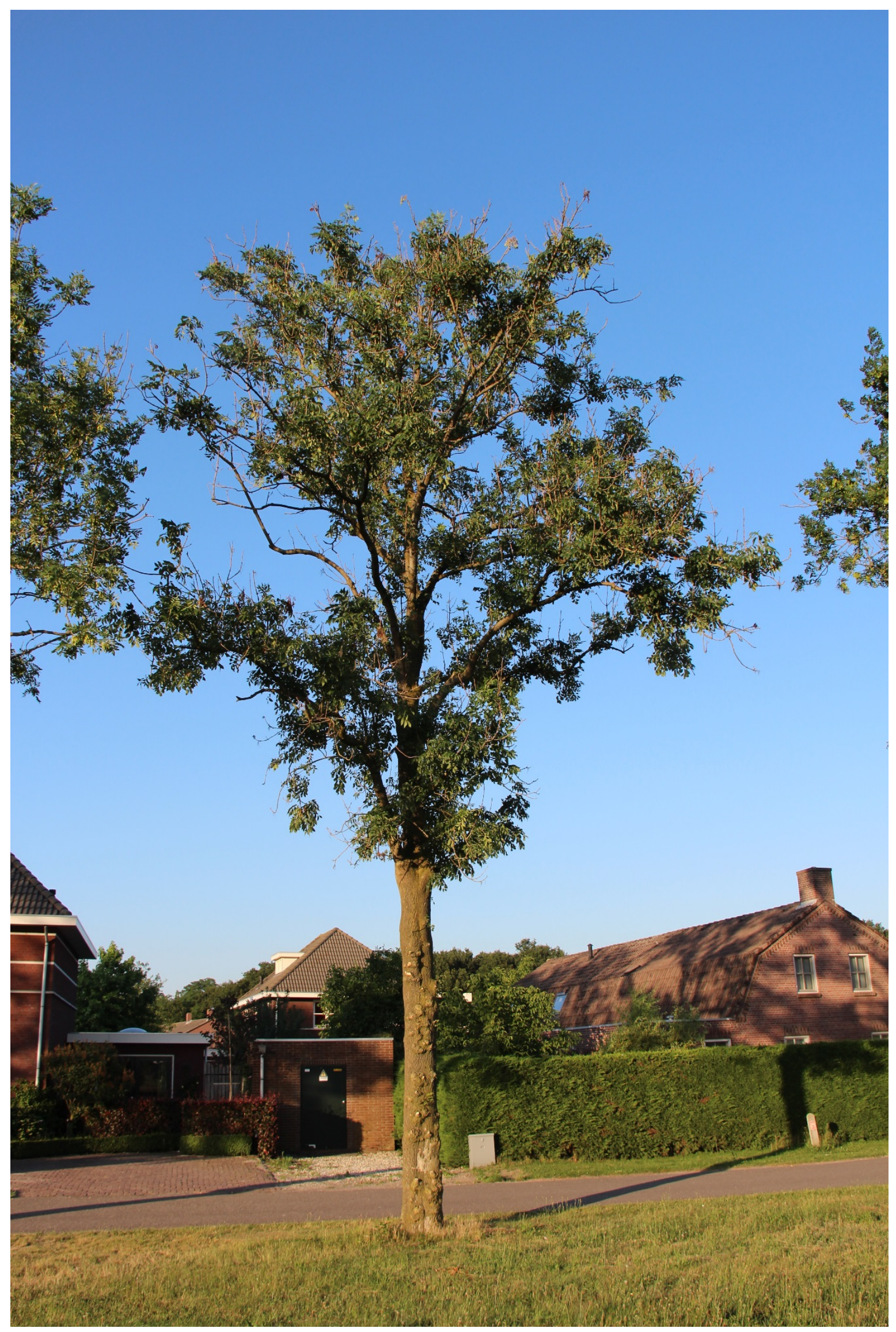

Foto 15b. Matige aantasting, ziekteklasse 2 (tabel 4) 


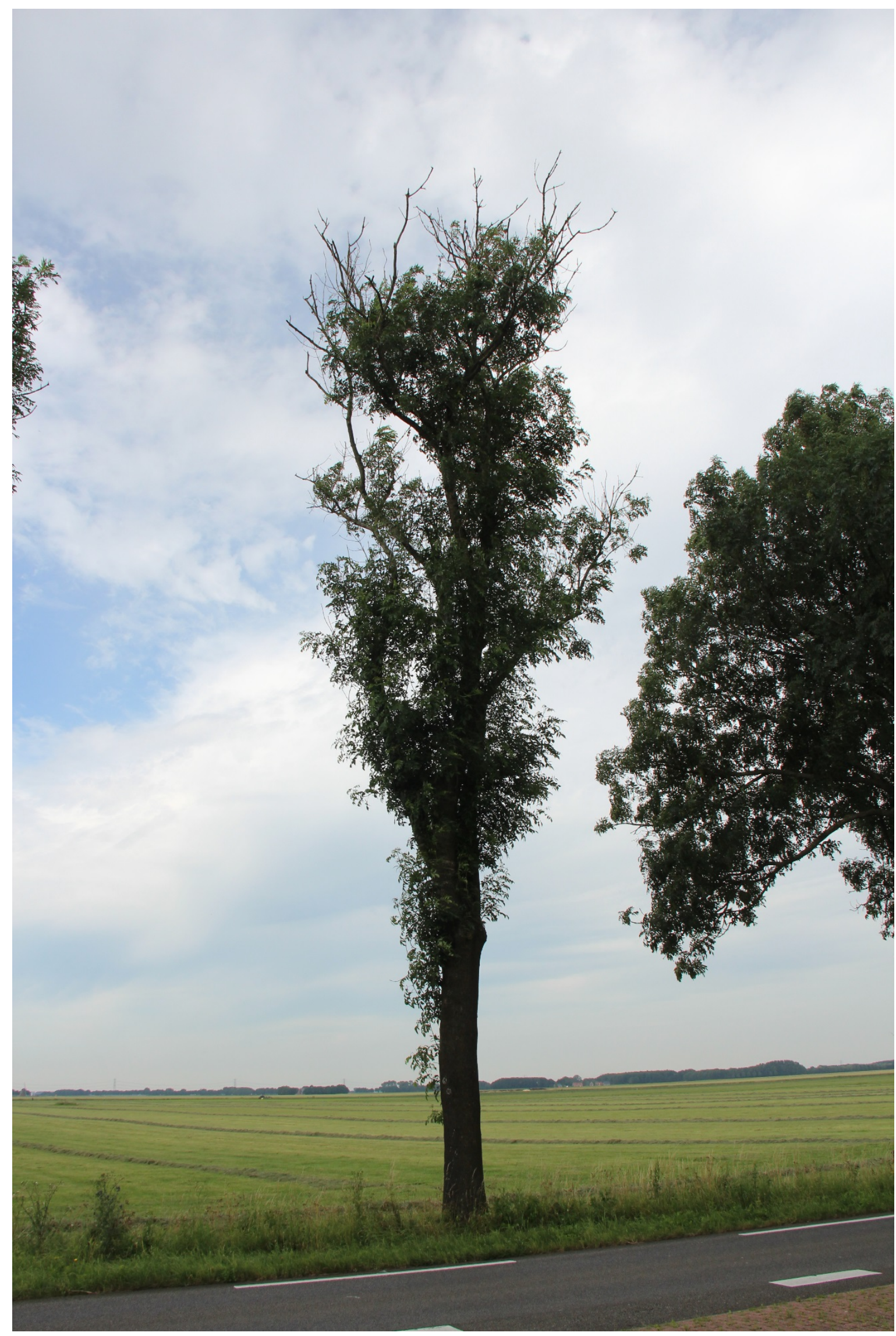

Foto 16a. Zware aantasting, ziekteklasse 3 (tabel 4) 


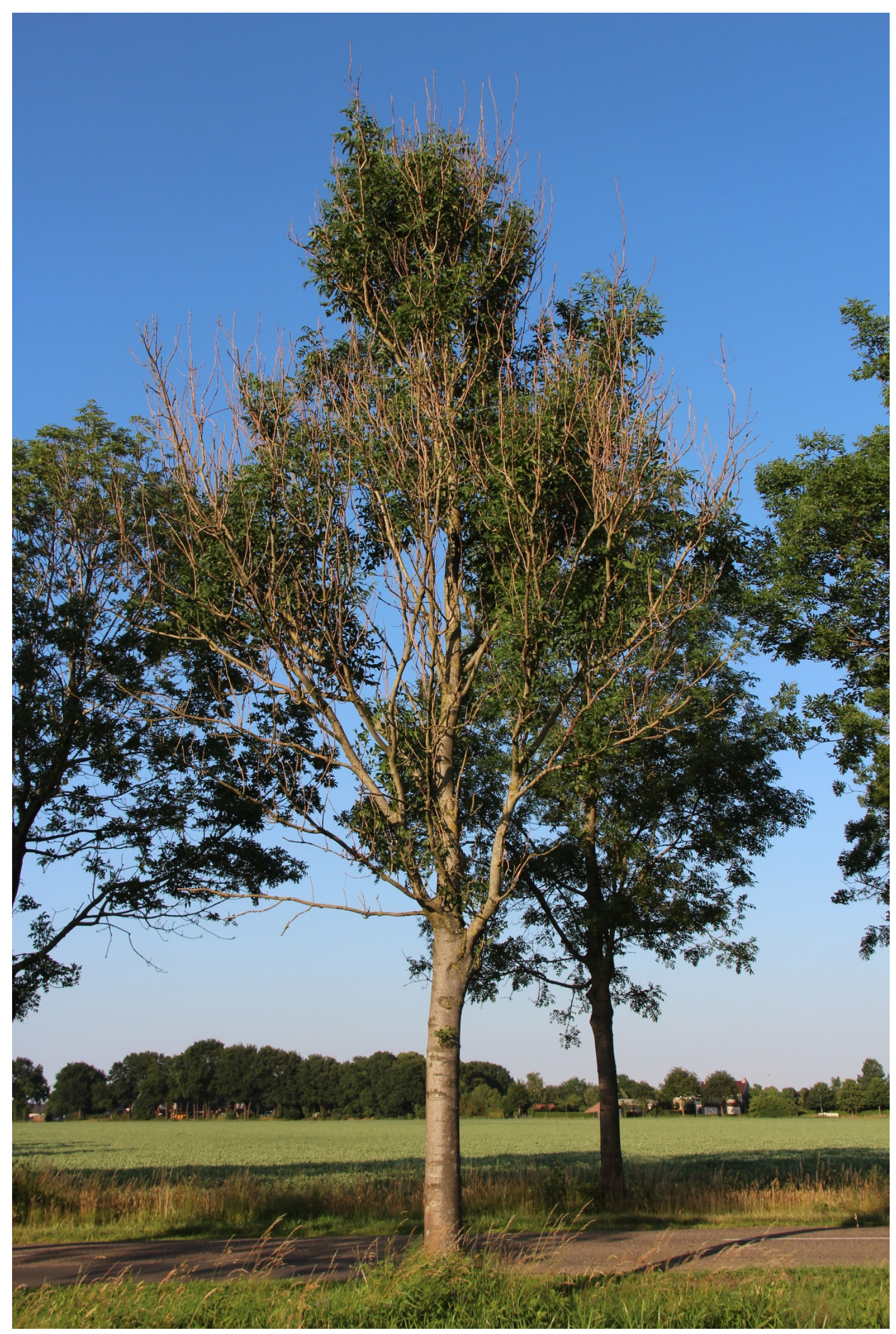

Foto 16b. Zware aantasting, ziekteklasse 4 (tabel 4) 


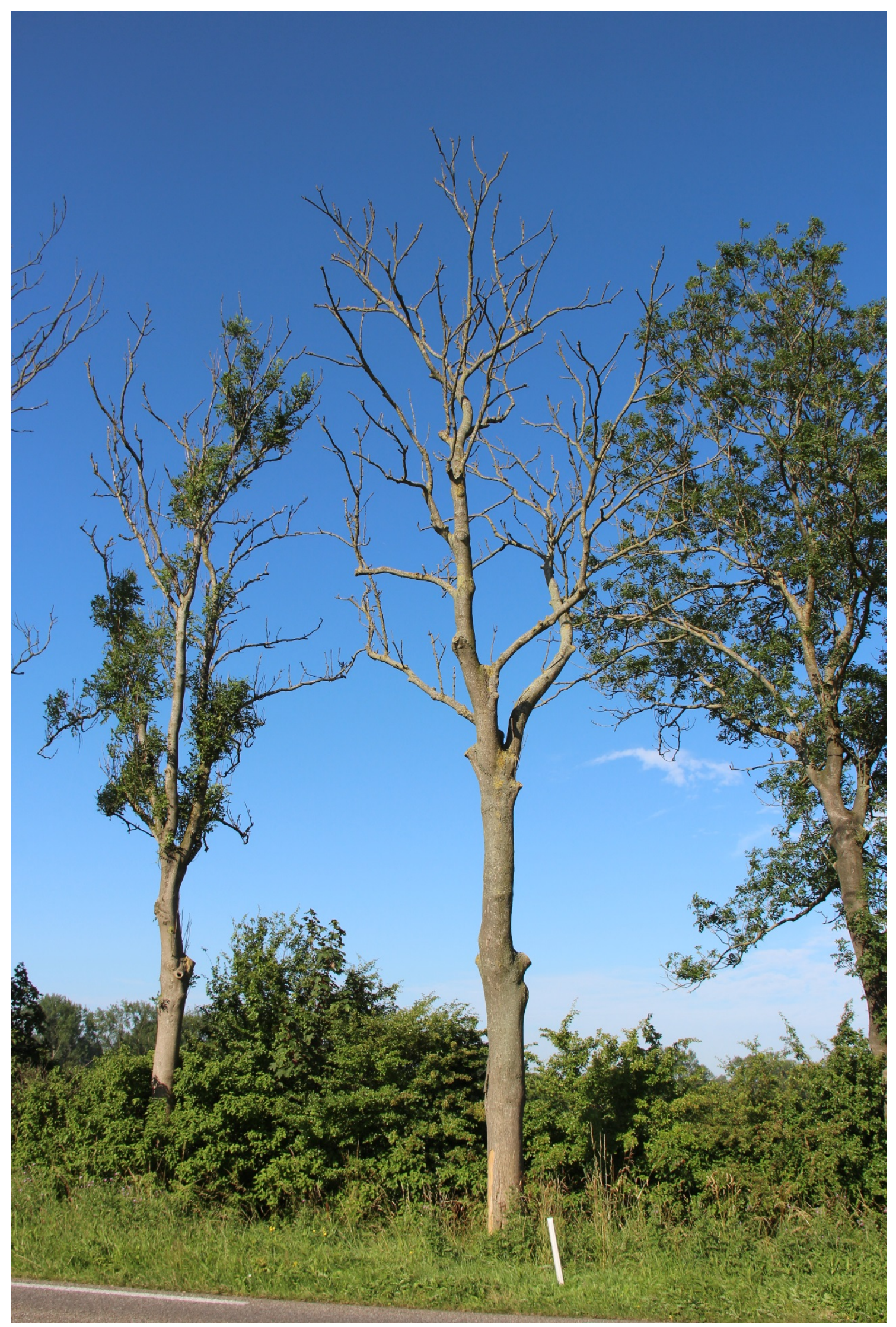

Foto 17. Dood, ziekteklasse 5 (tabel 4) 